\title{
Imperial Intentions and Independent Interests: The Ohio Company of Virginia and its Agents, Thomas Cresap and Christopher Gist,
}

\section{8--1752}

Emily S. Hager

West Virginia University

Follow this and additional works at: https://researchrepository.wvu.edu/etd

\section{Recommended Citation}

Hager, Emily S., "Imperial Intentions and Independent Interests: The Ohio Company of Virginia and its Agents, Thomas Cresap and Christopher Gist, 1748--1752" (2011). Graduate Theses, Dissertations, and Problem Reports. 704.

https://researchrepository.wvu.edu/etd/704

This Thesis is protected by copyright and/or related rights. It has been brought to you by the The Research Repository @ WVU with permission from the rights-holder(s). You are free to use this Thesis in any way that is permitted by the copyright and related rights legislation that applies to your use. For other uses you must obtain permission from the rights-holder(s) directly, unless additional rights are indicated by a Creative Commons license in the record and/ or on the work itself. This Thesis has been accepted for inclusion in WVU Graduate Theses, Dissertations, and Problem Reports collection by an authorized administrator of The Research Repository @ WVU. For more information, please contact researchrepository@mail.wvu.edu. 
Imperial Intentions and Independent Interests: The Ohio Company of Virginia and its Agents, Thomas Cresap and Christopher Gist, 1748-1752.

\section{Emily S. Hager}

Thesis submitted to Eberly College of Arts and Sciences at West Virginia University in partial fulfillment of the requirements for the degree of

Master of Arts in History

Tyler Boulware, Ph.D., Chair

Joseph Hodge, Ph.D.

Brian Luskey, Ph.D.

Department of History

Morgantown, West Virginia

2011

Keywords: The Ohio Company of Virginia, Thomas Cresap, Christopher Gist, Agents of Empire, British Expansion, Borderlands, 


\begin{abstract}
Imperial Intentions and Independent Interests: The Ohio Company of Virginia and its Agents, Thomas Cresap and Christopher Gist, 1748-1752.
\end{abstract}

\title{
Emily S. Hager
}

Thomas Cresap and Christopher Gist, two common men from Maryland, began working for the Ohio Company of Virginia in 1748, in an attempt to expand the British Empire's claim in the Ohio River Valley by enlarging the colony of Virginia. This thesis analyses these two agents of empire and their trade and diplomacy with the Indians of the Ohio Valley, as well as their mapping and surveying. This thesis argues that these two "on the ground" agents were building the British Empire, through their work for the Ohio Company of Virginia. However, this was not their only imperial tie, there were many formal and informal ties that bound the Ohio Company to governmental officials. These ties often make it difficult to determine if Cresap and Gist were bring employed by the Ohio Company or the British Empire. This thesis explains the relationship between the Ohio Company, the Ohio Company employees and the British Empire and how the independent interests of the employees and the Company, made it possible for the British to expand into the Ohio River Valley, and compete in the race for empire in North America. 


\section{Dedication}

For the local and public historians of western Maryland, who refused to let local history fade.

\section{Acknowledgements}

Many individuals made this thesis possible. Jilla Smith encouraged me to pursue this topic, and gave me the priceless gift of confidence. Bob Bantz led me to rare resources, but more importantly, he gave his time. Hiking Braddock's road with Mr. Bantz, who knows the locations of skirmishes, deaths and graves, allowed me an unprecedented connection to the past. Dr. Tyler Boulware, Dr. Joseph Hodge and Dr. Brian Luskey introduced me to new ideas challenged my concept of "history." Their guidance in navigating graduate school was invaluable. Most of all, I thank my family for their love and support. Also, I thank Brian Kasecamp, my fiancé, who, I am sure, has learned far more about Thomas Cresap than he ever desired. Finally, I thank my father, Dr. Charles Hager, who is confidant, editor, and sounding board. Without his guidance, this thesis never would have reached completion.

\section{Table of Contents}

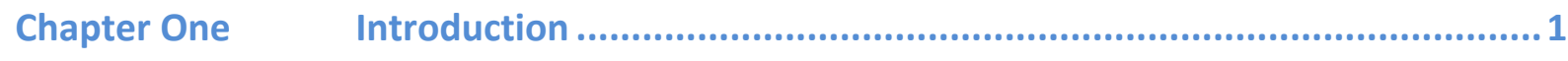

Chapter Two Crown and Company.......................................................... 10

Chapter Three $\quad$ On the Ground Agents.............................................................. 38

Chapter Four $\quad$ Epilogue............................................................................... 74

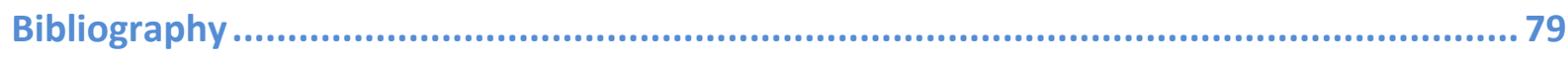

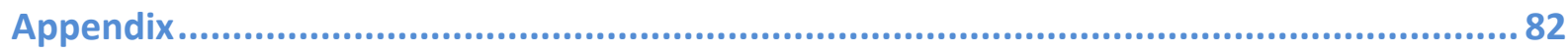

Curriculum Vitae ........................................................................................ 85 


\section{Chapter One}

\section{Introduction}

"Fathers, Both you and the English are white, we live in a Country between; therefore the Land belongs to neither one nor t'other: But the Great Being above allow'd it to be a place of Residence for us so Fathers, I desire you to withdraw, as I have done our Brothers the English; for I will keep you at Arms length: I lay this down as a Trial for both, to see which will have the greatest Regard to it, and that side we will stand by, and make equal Sharers with us."

\section{Tanaghrisson $^{1}$}

This speech given to the French Captain Marin in 1753, speaks volumes about the situation in the Ohio Country. ${ }^{2}$ As Tanaghrisson so eloquently phrased, the "Country between" was highly contested. As the British and French pushed into the Ohio Country, the Iroquois, Twightwee and Shawnee did their best to keep the Europeans at bay. ${ }^{3}$ Despite the diplomacy of Indians such as Tanaghrisson, the British and French governments were unwilling to halt their expansionary activities due to their fear of falling behind in the race for empire and losing the monetary benefits of conquering the North American continent.

Due to the diverse number of people who had an interest in the Ohio Country, empire building there was not monolithic. Each country and colony had its own method, objective,

\footnotetext{
${ }^{1}$ The Spelling of the "Half-King's" name varies so many times in various publications and primary sources that it would be impractical to list the variations. Tanaghrisson is the spelling that is used here.

${ }^{2}$ Francis Jennings, Empire of Fortune (New York, W.W. Norton Co.: 1988) 46. This speech, which was given to the French Marin, was actually recorded by George Washington.

3 "Twightwee" is often spelled "Twightwee" and often are simply called "Miami". This paper follows Christopher Gist's lead and employees the term "Twightwee."
} 
and reason for pushing into the Ohio River Valley. Although the British were greatly interested in obtaining these lands, no British governmental officials roamed the backcountry of the American Colonies. Instead, traders, trappers and debtors were the only British subjects present. This thesis shows that some of the "common men" who lived and toiled in the Ohio Region actively worked for the expansion of the British Empire and that their actions led in part to the international conflict known as the Seven Years' War. ${ }^{4}$ These white traders did far more than carry goods from the coast to the Ohio Valley; they literally shaped the British Empire. They claimed lands, engaged in diplomacy and sent reports across the Atlantic. Their letters, journals and maps determined the politics of Britain, and hence, shaped international events.

This thesis examines the imperial nature of two backwoodsmen from 1748 until 1752 through an investigation of one of the earliest land speculation companies in Colonial America, the Ohio Company of Virginia. The study of two individuals, Thomas Cresap, one of the founding members, and Christopher Gist, the Company's most important employee, are the means of proving that the actions of common men drove British expansion in the mid1700s. Gist and Cresap, via their actions in pursuit of commercial enterprise for the Ohio Company of Virginia, influenced the imperial contest on the trans-Appalachian frontier, and in turn, their actions led to the clash between Britain and France over the interior of North America. These two agents of empire stretched the connections of the British Empire westward to the Appalachian Mountains and beyond. Thomas Cresap and Christopher Gist, through their connection to the Ohio Company of Virginia, engaged in empire building during

4 Stephen Aron and Jeremy Adelmen, "From Borders and Borderlands." American Historical Review (June, 1999), 814. Borderland in this thesis means a disputed area of land where multiple parties have land claims, but ownership has not yet been determined. This term will be discussed at length further in the introduction. 
this time period. This thesis shows that the backcountries and its inhabitants warrant an active role in the studies of the British Empire and the international contest for the Ohio Valley. No other research has linked the capitalistic venture of the Ohio Company and the self-interested imperial activities of its agents, Thomas Cresap and Christopher Gist, to the expansion of the British Empire into the Ohio Country and the subsequent Seven Years' War.

Before the outbreak of the Seven Years' War, the majority of the British colonists in the backwoods of the American colonies considered themselves to be loyal subjects of the crown. In the westernmost regions, Anglo-American colonists identified themselves, and the land on which they lived, as a part of the British Empire. Some of these backcountry peoples had little doubt that they (and the backcountry in which they lived) were connected to governmental affairs in London. ${ }^{5}$ In the historiography of colonial America, however these individuals appear to be disconnected and disengaged from the British Empire because it is difficult to imagine the actions of a few ragtag explorers and traders, who resided in uncharted and uncertain land, having any bearing upon international events. This misconception is overdue to be challenged. Backwoodsmen, traders, and explorers were part of the British Empire and played a key role in instigating the Seven Years' War. These men engaged in Indian diplomacy, surveying, mapmaking and trading, as well as fort construction and road building for the Ohio Company of Virginia. ${ }^{6}$ These commercial activities, performed while

\footnotetext{
${ }^{5}$ Mathew Ward, Breaking the Backcountry: The Seven Years' War in Backcountry Virginia and Pennsylvania, 1754-1765, (Pittsburgh: University of Pittsburgh Press, 2003). Backcountry, as it is used in this thesis, means the area that is legally part of the British Empire, and is loosely organized into counties and communities, but it is not as socially and political established as the east coast areas. It is still in many cases "wilderness" or "frontier". This backcountry is not a part of the "disputed territory."

${ }^{6}$ Hereafter, this is referred to as "The Ohio Company" or "the Company" not to be confused with the post-Revolution land speculation company of that same name that was formed in New England.
} 
slogging through fetid swamps and icy Appalachian waterways, translate into imperial actions that advanced the cause and claim of the British.

Eric Hinderaker is one of the few historians who argues that the construction of the British Empire in the interior of North America came largely from the people who lived and worked in the Ohio River Valley. ${ }^{7}$ In his book, Elusive Empires, Hinderaker stresses that the peoples trading, living and trapping between the rhododendron thickets and hemlock tangles may have had more influence over the actions in the Ohio Country than officials in Paris or London. ${ }^{8}$ Indeed, Cresap and Gist had immense and often unchecked power in the disputed territory, and had more of an influence on empire building there than governmental officials in London. Hinderaker also explains that empires constitute a series of processes rather than imposed structures. ${ }^{9}$ This thesis explains how Gist and Cresap, the imperial agents in question, carried out the processes that were necessary to bring the Ohio Valley into the British Empire. This paper holds that empire building processes flexed and intertwined, due to the nature of the interdependent relationship of private and public interests that together pushed Anglo-American colonists westward. Thomas Cresap and Christopher Gist built the empire by trading and negociating with Indians, and by surveying and mapmaking the Ohio River Valley. Their roles were constantly changing, as Cresap and Gist adapted to fit the needs of the moment.

Where Hinderaker focuses on the variations of empire building in the British American colonies, Fred Anderson's master narrative, Crucible of War, focuses on the larger story of empire in America. Anderson's work, which links London to the Ohio River Valley,

\footnotetext{
${ }^{7}$ Eric Hinderaker, Elusive Empires: Constructing Colonialism in the Ohio Valley, 1673-1800, (New York: Cambridge University Press, 1997), 24.

${ }^{8}$ Hinderaker, Elusive Empires, 25.

${ }^{9}$ Hinderaker, Elusive Empires, 25.
} 
is crucial to understanding the circumstances in which the Ohio Company's agents worked. Crucible of War also explains nature of the Ohio Company's connections to London. ${ }^{10}$ Anderson explains that connections between London and the America colonies did exist, but that the great distance across the Atlantic meant that these relationships did not always have the characteristics that are typical between an empire and its colonies. Besides adding to the understanding of trans-Atlantic colonialism, Crucible of War also details the politics of the borderland that led to international conflict between France and Briton. Anderson hypothesizes that the Seven Years' War 'is a war that began when the diplomatic miscalculations of the Six Nations allowed the French and British Empires to confront each other over control of the Ohio."11 This thesis details the actions of those agents of empire who were involved in the earliest clashes. Thomas Cresap and Christopher Gist, employees of the Ohio Company, laid the foundation for the British Empire and manipulated the Iroquois situation in the Ohio Valley. These two men are crucial to understanding the Iroquois Empire's inability to keep French and British apart in the borderlands.

Most historians view George Washington's westward missions as the start of FrenchBritish hostilities, but that conflict began long before Washington ever set foot in the Ohio region. It was Cresap's and Gist's conflicts with the French in the borderlands that triggered Governor Dinwiddie to send George Washington to Fort Le Bouf. This thesis is centered around the events and actions that led to the escalation in British-French hostilities. Despite the fact that an uneasy peace had been established between Britain and France in 1748 with

\footnotetext{
${ }^{10}$ Fred Anderson, Crucible of War: The Seven Years' War and the Fate of Empire in British North America, 1754-1766. (New York: Viking, 2005).

${ }^{11}$ Anderson. Crucible of War, ii. A similar view is expressed in Colin Calloway, The Scratch of a Pen, 1763, and the Transformation of North America (Oxford: Oxford University Press, 2006).
} 
the signing of the Treaty of Aix-la-Chapelle, Cresap and Gist's activities did not cease. The actions of French and British diplomats across the Atlantic meant little to trappers and Indians in the Ohio Country. This thesis focuses on "peace time" clashes and those whose vested interests caused the continuance of confrontations from 1748 until 1752. Two men's endeavors for the Ohio Company of Virginia during this time shed additional light on the actions and motivations of the British in the international struggle for empire. Cresap and Gist's imperial actions are crucial to understanding the full escalation of British and French hostility that led to the Seven Years' War.

At this point in this discussion, it becomes prudent to define the concept of "borderland." As explained by Jeremy Adelmen and Stephen Aron, "borderland" is the contested land between empires, where all have land claims, but ownership has yet to be determined. ${ }^{12}$ The borderland only remained so because of the Indian presence within. The Iroquois and other Indian groups played the British and French against one another to extend the period of Euro-centric uncertainty in the Ohio region. As long as one group did not triumph over the other, the Indians were able to maintain and even extend their grasp on the Ohio Country. Had it not been for the control the Indians exercised in the "borderlands," Cresap and Gist would not have had the chance to prove their imperial tendencies, nor would their westward movements have had any outstanding repercussions on the wider world.

The Ohio Valley was not only a borderland between European empires, but it was also a source of colonial conflict. The inter-colonial rivalries of Pennsylvania, Virginia and Maryland over the Ohio Valley led to hostilities between residents and governmental officials. Cresap and Gist's travels highlight the relationships between the traders and explorers from

12 Aron and Adelmen, 814. 
various colonies as they claimed the land and trading rights for their own constituencies. The actions of the Iroquois and Ohio Indians demonstrate that it was not only European powers fighting for control of the Ohio Country. There many groups who struggled to manipulate and change the circumstances to gain land and rights for themselves. Clearly, the forces of empire building were not monolithic as each group chose different mechanisms and manners to advance their claim.

Although the Indians of the Ohio Valley are not the center of this study, it is crucial to understand that they too were not cohesive but vastly diverse. In order to understand the politics of the borderland, and hence the actions of the Ohio Company agents, it is necessary to recognize the divisions and struggles of the Ohio Indians and those of the Iroquois Confederacy. The Ohio River Valley encompasses parts of fourteen modern-day states. In the mid-eighteenth century, Indians who had different customs, lifestyles and manners of governance inhabited this vast region. The Delaware, Shawnee, Miami, Wyandot, Potawatomi, Wea, Piankashaw, Ottawa and Ojibwa were just a few of the many groups with whom Gist and Cresap engaged to further the Ohio Company's goals. Gregory Evans Dowd emphasizes in his work, "there was no single Indian outlook," and this fact made Cresap and Gist's assignments for the Ohio Company extremely difficult, as there were endless bands and groups of Indians to meet with and attempt to sway to the side of the British. Gist's journeys constitute the first British contact for many Indians in this region, and Cresap's Oldtown Trading Post introduced British goods and ideas at the intersection of the "Warriors Path" and the primary east-west riverine, the Potomac.

There is a dearth of recent scholarship on the Ohio Company, Thomas Cresap and Christopher Gist, thus earlier scholarship proved particularly useful to this study. Kenneth 
Bailey has written three books that are crucial to this discussion: one on the Ohio Company of Virginia (1939), one on Thomas Cresap (1944), and one on Christopher Gist (1976). ${ }^{13}$ Bailey is the first historian to include Thomas Cresap as one of the founders of The Ohio Company, and he asserts that the Ohio Company and Thomas Cresap are crucial to the story of westward expansion and the Seven Years' War. His third and final book, published some time later, is on Christopher Gist. Bailey notes that for the Gist biography more primary resources were available, and thus his third book is more complete than the other two. This study intends to look more closely at those individuals working "on the ground" to explain their work not only as land speculation, but also as empire building. Bailey's books, while informative, do not address many of the changes that have taken place in the historiography regarding transAtlantic relationships and the involvement of Indians. By connecting the Ohio Company to those making decisions in London, and putting agency in the hands of the Indians, this thesis shows empire building in a new light.

The Ohio Company's purpose was to make a profit, but it was not just a moneymaking scheme; it was also about expanding the British Empire by enlarging the colony of Virginia. Since the lands that the Virginians coveted were not uninhabited, the success of the Ohio Company depended on the ability of its employees to create and maintain positive relationships with various bands of Indians in the disputed region. Gist and Cresap, as agents of the Company and its expansionist policies, represented and symbolized the British Empire in the disputed Ohio Country. Thomas Cresap and Christopher Gist form the core of this study. The first chapter of this thesis begins with a brief biography of each man and then

\footnotetext{
${ }^{13}$ Kenneth Bailey, The Ohio Company of Virginia and the Westward Movement, (Lewisburg, Pennsylvania: Wennawoods Publishing, 2000). Kenneth Bailey, Thomas Cresap: Maryland Frontiersman, (Boston: Christopher Publishing House, 1944). Kenneth Bailey, Christopher Gist: Colonial Frontiersman, Explorer and Indian Agent. (Hamden: Archon Books, 1976).
} 
compares their circumstances, and assesses the characteristics the Ohio Company needed in its agents. This is followed by an explanation of the politics surrounding the formation of the Ohio Company in the colony of Virginia, and the complications that ensued. Chapter One details the relationship between company, colony and Crown, and how that relationship worked to build the British Empire in the Ohio Country. The second chapter focuses on the specific actions of the men working for the Ohio Company in the disputed territory. It begins with a report of Cresap's actions for the Ohio Company, and is then followed by descriptions of Gist's two excursions into the Ohio Country. The next section details their collaborative work, and concludes with an explanation of the immediate effects of their actions on the politics of the Ohio region and on international events. Following Chapter Two, there is a brief epilogue, where further information regarding Cresap and Gist's continued work for the Ohio Company and the Empire is outlined. It discusses the fate of each man, and that of the Ohio Company of Virginia and the British Empire. The epilogue also details how the fight for land in the Ohio region would eventually be the wedge that drove the British away from these backwoodsmen who had once been the British Empire's greatest advocates. 
"Your Petitioners who are the first Adventures in this Beneficial Undertaking which will be so adventageous to the Crown in point of Revenue, to the nation in point of trade and to the British Colons in point of Strength and Security most humbly pray that Your Majesty will be graciously pleased to encourage this their said undertaking"14

\section{Petition of the Ohio Company of Virginia}

This small piece of the Ohio Company's petition to the Board of Trade showcases the members' views on the benefits of land-speculation in the Ohio Country, and shows their intended relationship to the Crown. It is necessary to examine the nature of this enterprise and its imperial connections in order to evaluate the men working in the Ohio Country as empire builders. A brief history of the founding of the Ohio Company of Virginia demonstrates that the actions of the members and employees of the Company were imperial in nature. The Ohio Company, the Virginia government, and the British Ministry became tightly intertwined in the struggle for the Ohio Country. It is thus necessary to underline this imperial connection and the indistinguishable nature of private and public spheres in colonial Virginia. Without this distinction, Cresap and Gist are just two colonists in buckskins who rummaged around the backwoods of the British Empire; their work for the Ohio Company becomes disconnected from empire building. The imperial nature of their employer, the Ohio Company, therefore sets these two men apart from other backwoodsmen in the Ohio Country.

\footnotetext{
14 "Petition of John Hanbury to the King on behalf of the Ohio Company", 1748. Bailey, The Ohio Company of Virginia, 300.
} 
Cresap and Gist knew they were actively building the British Empire, and worked directly and other times indirectly, with the Board of Trade. ${ }^{15}$

This chapter strives to show the many connections and overlaps of the Ohio Company and the British government. By showing the connections of the Company to the Crown, Cresap and Gist are proven to be more than just traders and trappers. The imperialistic ties of the Ohio Company members result in their employee's transformation into agents of empire. By discussing the origins of the Ohio Company, the political and social makeup of the members and the employees and then identifying the differences of the Ohio Company employees and the Pennsylvania traders, we can showcase the imperialistic nature of the Company of Virginia.

It was the Ohio Company's relationship with the Board of Trade that allowed them to set the tone for how the American interior would be explored. In his book, Empire of Fortune, Francis Jennings writes, “The Ohio Company forced the pace of British expansion."16 Jennings gives the Ohio Company credit for how the American West was opened, and how the British expanded their empire, and rightfully so. The Thirteen Colonies, and bits of present-day Canada, were the only lands claimed by the British in the "New World"; they had fallen behind in the race for empire and allowed France to take the lead. If one follows Jennings' logic, it was a colonial American private enterprise, The Ohio Company, which allowed the British to catch up with the French, Spanish and Dutch in the race for empire.

\footnotetext{
${ }^{15}$ In the Making and Un-Making of Empires, J.P. Marshall points out that not all expansion done by Britons was imperial. I do agree with Marshall, however, the connections of the Ohio Company to the Board of Trade and the nature of the Company's goals show that the their actions were imperial.

${ }^{16}$ Jennings, Empire of Fortune, 17.
} 
While historians like Francis Jennings and Fred Anderson give due credit to the Ohio Company for its actions and their impacts on the borderland, they fail to say who was responsible for carrying them out. It was Thomas Cresap and Christopher Gist, braving subzero temperatures, wild animals, incited Indians, Couriers de Bois, personal health issues, perilous river crossings, hunger, thirst and heat who catapulted Britain back into the race for empire in North America. It was the actions of these little known and hardly recognized men that helped to establish "the empire on which the sun never set."

In 1748, wealthy and intelligent patrons, such as the Lee and Fairfax families, were willing to spend money to realize the Ohio Company's ambitions. However, most of these men were neither capable nor disposed to travel into these dangerous and largely unknown lands to further the Company's mission. Thus, before delving into the intricacies of the Ohio Company's complex set of imperial and governmental relationships, the men who largely undertook these risks, Christopher Gist and Thomas Cresap, need to be introduced.

\section{Christopher Gist}

Christopher Gist's background is crucial to understanding his actions and motives in the Ohio Country. It can also be determined by looking at Gist's life what the Ohio Company was looking for in an employee. We can therefore gain an understanding of the type of frontier activities they wished to participate in by analyzing the resumes of their first and most active employee.

Christopher Gist was born in Baltimore, Maryland in 1705. The earliest existing record regarding Gist is his marriage license to Sarah Howard, the daughter of a wealthy Baltimore merchant. Although Gist never amassed great wealth, the Gist family, including Christopher, was well established in Baltimore financially and socially. Gist held several 
minor positions within the colonial government and was active in trading and trans-Atlantic commerce.

Among the other fur traders and Indian agents of the mid-eighteenth century, Gist stands out because he was educated. Contemporaries and historians alike noticed his extensive education. He wrote well and was formally trained in surveying and mathematics. Apart from his formal academic education, Gist was also extremely well mannered. While his family was not of the aristocracy, Gist had grown up in Baltimore society, thus he knew enough about proper social graces to always be welcomed into the Fairfax Mansion. One might argue that this training and intellect would be of little use in the rugged Ohio Country, but without this education, Gist would not have been able to carry out his later missions for the Ohio Company of Virginia.

Even though Gist had grown up in the city of Baltimore, he did not confine himself to its borders. Gist began his career serving in Maryland's Rangers. The Rangers were a special unit of the Maryland militia whose members were chosen for their knowledge of the surrounding area and the "frontier." In this position, Gist did not protect the colonists from the Indians, which would have been a very dull job, for Indian raids in Baltimore were scarce at that time. Instead, he helped build and maintain the "Ranger Road" which was a wagon road leading to and from Baltimore to present day Frederick, Maryland. As the name implies, the Maryland Rangers built the road. Following the road's initial construction, Gist was the sole Ranger who maintained the thoroughfare, requiring him to spend much of his time traveling up and down the road. ${ }^{17}$ Gist's experiences with the Maryland Rangers prepared him for his later excursions into the Ohio Country.

17 Bailey, Christopher Gist, 23. 
Throughout Gist's early life he worked as a merchant, and is known to have owned at least one ship that transported trade goods to and from England. Despite his wanderlust, Gist prospered in his youth. Unfortunately for Gist, he ran into personal financial trouble that would cause him to become a debtor for the rest of his life. When Gist was nineteen, he followed in his father's footsteps by working as an agent for the British Fur Company. For eight years, he labored in the fur industry without incident, but in 1732, disaster struck. A warehouse filled with furs burnt down, and the British Fur Company held Gist responsible for the debts he owed to them. They charged Gist with a claim of 10,000 pounds sterling for the damages. ${ }^{18}$ Gist responded by relocating to the Carolina backcountry, which was at the time the newest "American Frontier."19 Gist paid on the 10,000-pound claim for the rest of his life, but never to the satisfaction of the British Fur Company. This continuous strain is why Gist never became wealthy, and explains his relentless ambition despite his failing health. ${ }^{20}$ Despite the best efforts of friends such as Lawrence Washington and George Mercer, Gist's fortune did not improve.

As much sorrow as the fur business gave Gist, it was the lessons and experiences that he learned while practicing the trade that would later benefit him, the Company, and the British Empire. Through his trappings and trading, he came to know the country between Williamsburg and present day Pittsburgh extremely well. Gist's biographer, Kenneth Bailey, asserts that Gist knew that stretch of land better than any of his contemporaries, and Gist's

${ }^{18}$ Bailey, Christopher Gist, 23.

${ }^{19}$ Bailey, Christopher Gist, 23.

${ }^{20}$ Gist did get back on his feet while in the employ of the Ohio Company. He established "Gist's Plantation" (referred to in journals and on maps simply as "Gist's") and achieved some finanical stability. However, his residence was soon burnt to the ground by pro-French Indians, and he was denied compensation by the government. For Gist's request for compensation see Bailey, Christopher Gist, 156. 
contemporaries seem to agree. He later served as a guide for both George Washington and General Edward Braddock on their various westward journeys to the Ohio Country, and he was always the man Governor Dinwiddie would call upon when he needed a scout or guide to accompany troops or individuals into the Ohio Region. ${ }^{21}$ Not long after Gist relocated to the Yadkin River Valley, the Ohio Company of Virginia recalled him north. At the suggestion of Thomas Cresap, The Ohio Company employed Gist to explore the vast unknown that was the Trans-Appalachian Frontier.

\section{Thomas Cresap}

Thomas Cresap, "who had so much courage that is seemed to seep out of his very pores," according to one author, was one of the men who had the bravery and survival skills to go into the Ohio River Valley and claim unknown lands for the British Empire. ${ }^{22}$ Cresap's background, while a thrilling tale in its own right, allows an understanding of his actions, why he took them, and how he gained the knowledge that was crucial to his successful ventures in the Ohio Country.

Cresap's own accounts, and other supporting documents estimate that it was around 1715 when Thomas Cresap emigrated to America alone around the age of fifteen, from Skipton, England. ${ }^{23}$ Cresap's life in America was apparently uneventful until 1727 when he married Hannah Johnson from Baltimore County. ${ }^{24}$ After the two were married, Cresap fled

${ }^{21}$ Don Larrabee, Edited and Complied, George Washington and Christopher Gist, A Reprint of The Journals of George Washington and his Guide, Christopher Gist, (Williamsport: 1950).

${ }^{22}$ Allan, Eckhart. The Wilderness Empire. Boston: Little, Brown and Company, 1967.

${ }^{23}$ Allen Powell, Forgotten Heroes of the Maryland Frontier (Baltimore: Gateway Press, 2001), 119. Cresap's exact age was unknown to him, and continues to be elusive to historians today.

${ }^{24}$ Powell, Forgotten Heroes, 119. 
Maryland into Virginia, without his wife, to escape debt collectors. ${ }^{25}$ Despite having made a few influential friends in Virginia, Cresap soon returned to Maryland and found his wife Hannah unwilling to move to Virginia. Hannah was apparently not opposed to moving, for the Cresap family soon relocated to the disputed Pennsylvania/Maryland border.

Once established in what today is known as Wright's Ferry, Cresap threw himself into the Conjacular War. ${ }^{26} \mathrm{He}$ fought for Maryland and its proprietors, the Calvert family, over the location of the Mason-Dixon Line, the boundary that separated Maryland from Pennsylvania. ${ }^{27}$ While he fought in this war, Cresap gained an infamous reputation among the Pennsylvanians that would stick with him throughout his career. It was during this time that Cresap gained the notable and somewhat humorous nickname, "The Maryland Monster," for his stubborn and vicious defense of Maryland's land claims. Cresap, upon being caught by the Pennsylvanians, was taken to the Philadelphia jail, where he spent sometime until Maryland and Pennsylvania formed an agreement for his return to the colony of Maryland.

It is during this inter-colonial war that Hannah Cresap, Thomas' wife, gained her fame among the Pennsylvanians as a fierce enemy and combatant; she fought alongside Thomas and often acted as a lookout and a scout for her husband's raiding parties. ${ }^{28}$ When the Pennsylvanians came to attack the Cresap home, Hannah was alone and seven months pregnant, however she fought them off and shot one of her attackers. It is partially due to Hannah's tough demeanor and ability with a rifle that later enabled Cresap to maintain a fortified home on the edge of the British Empire.

\footnotetext{
${ }^{25}$ Powell, Forgotten Heroes, 120.

${ }^{26}$ For details of Thomas and Hannah Cresap's involvement in the Maryland-Pennsylvania dispute, and on the Conjacular War in general, see Bailey's Thomas Cresap, Maryland Frontiersmen for more information.

${ }^{27}$ Bailey, Thomas Cresap, Maryland Frontiersman, 52-56.

${ }^{28}$ Powell, Forgotten Heroes of the Maryland Frontier, 124.
} 
Thomas Cresap and his family were eventually driven out of Conjacular Valley by the Pennsylvanians. The final straw came when the Pennsylvanians burned their house to the ground, (reportedly setting it on fire while Thomas and Hannah were still inside). The Cresap family persevered, moving to an area of land near present day Frederick, Maryland. This land was given to them by the Calvert Family as reward for their loyalty and military action during the Conjacular War. ${ }^{29}$ This is the first instance of Cresap receiving land compensation for his actions, and he quickly learned the benefits of working on behalf of a colony. He would continue this practice throughout his life.

Debts again haunted Cresap. Through his connections to the Maryland Government, he was able to sell his land in Frederick to the Calvert's lawyer and representative, Daniel Dulany in order to settle his debts. Later, the Calvert Family would again help Cresap, when Dulany arranged for Cresap to receive a large land grant, this time from the King, which enabled him to prosper in his later years. This grant was for the "Indian Field" or the "Old Shawnee Town" in the far western corner of Maryland, present day Allegany County. Here Cresap built a home and attempted to christen the area, "in a moment of uncharacteristic nostalgia," "Skipton.,"30 The name never stuck and afterward the location was either referred to as Oldtown, Cresap's or Cresap's Fort. ${ }^{31}$ The remains of his fortified home can still be found, in present day Oldtown, Maryland. By the time Cresap moved to his final home in Oldtown, he had spent his entire adult life working on behalf of the Maryland government, and was repaid in land (his land grant in Oldtown) and favors (Pennsylvania prison bailouts). The connections Cresap formed while working and fighting for the Empire and for Maryland

\footnotetext{
${ }^{29}$ Bailey, Thomas Cresap, Maryland Frontiersman, 56.

${ }^{30}$ Bailey, Thomas Cresap, Maryland Frontiersman, 57.

${ }^{31}$ In some journals and travelers' accounts "Cresap" is often spelled many different ways, with the move common variations being "Crissap", "Cressop" and "Cressips."
} 
paid off, and obviously Cresap thought so too, for he continued this pattern of behavior, working in diverse ways for various colonies and the Empire in general.

When Cresap settled in Oldtown, he knew that the site was a major Indian thoroughfare, and he was instrumental in making that location one of the prime crossroads of the American frontier. By operating a trading post on the junction of the Potomac River and Warrior's Path (the trail the Iroquois used to attack the Indian bands of the southern Appalachians), Cresap was able to control much of the fur trade that occurred for miles around. The river ran east to west and the trail ran north to south, placing Cresap on the trade route nexus of the region. This trading post allowed him to overcome his previous troubles and finally obtain financial stability. By opening a safe haven for migrating families and providing trade necessities for Indians and colonists, Cresap guaranteed that he would have his hands in all the pies baking in the Appalachian Mountains and the land west, the Ohio Valley.

It was this location that allowed Cresap to become a specialist in Indian affairs. Cresap, cognizant of his venerable position, especially in the early years of his existence on the edge of Empire, was a kind and generous host to a diverse group of natives. Cresap gained another notable nickname, this time not one that indicated violence, but one that suggested generosity. He became known as "Big Spoon," because, according to reports, Cresap fed all those who passed by, colonists and Indians alike. In an attempt to placate the Indians to his presence, for example, Cresap allowed visiting bands to slaughter a head of his beef herd whenever passing through. Cresap was not eating these losses quietly, however, he constantly applied to Maryland, Virginia, Pennsylvania and London for compensation, but he rarely received any. George Washington's journals show just how common these events 
were, for he notes that while he was at Cresap's at the age of sixteen, he saw his first War

Dance and his first scalp. ${ }^{32}$ Cresap's years in Oldtown allowed him to observe various bands of Indians, their culture and language, and these experiences aided him in his work for the Ohio Company.

\section{Cresap and Gist Commonalities}

One of the commonalities that these two men shared was their early work for the colony of Maryland and their status as Marylanders. Although both engaged in service for Maryland, they spent the greater part of their adult lives, during which the most significant of their imperial actions took place, furthering the land claims of Virginia. ${ }^{33}$ It seems that neither Gist nor Cresap was afraid to let their colonial loyalties wane if it benefitted their pocketbooks. They engaged in work of this nature because it was a way to become financially stable, pay back their debts and, in Cresap's case, stay out of jail. While these two men were acting on behalf of the Crown, as well as for Maryland and Virginia, it is also clear that their own personal fortunes were of utmost importance. ${ }^{34}$ "Empire Building" was a means of gaining both wealth and status. ${ }^{35}$

\footnotetext{
${ }^{32}$ Bailey, Thomas Cresap, 27.

${ }^{33}$ Maryland did not participate in the for race empire in the Ohio River Valley in the same manner as her neighbors Pennsylvania and Virginia. This was not due to lack of motivation, however, but rather the nature of Maryland's charter, which specified a western boundary at the headwaters of the Potomac River. Other colonies lacked a fixed western boundary, giving them the legal ability to expand.

${ }^{34}$ Both Cresap and Gist were influential actors in the Seven Years' War, and Cresap miraculously still had steam left to take action during the American Revolution even though by that time he was too old to physically engage in fighting. Although they were no less important then, those sections of their lives are not dwelled upon in this paper, due to its focus on British Empire building. More information can be found on the later lives of Thomas Cresap and Christopher Gist in Kenneth Bailey's biographies.

${ }^{35}$ This would change after the Seven Years' War when the Crown attempted to restrict the westward expansion of the colonies in order to maintain peace with the Indians. This would include the Ohio Company's grant.
} 
Cresap and Gist had both worked for the government of Maryland, but not in a capacity that lent itself towards expansion, and they barely made a living, as neither man achieved any financial success until they turned their eyes westward. Cresap and Gist were informal agents of the Crown or at least the colonial governments. Their experiences with the Ohio Company were not their first encounter with the British Empire. Cresap and Gist knew the risks of government work, and both were willing to take the risk to achieve success. Ambition drove not only the Ohio Company's investors to engage in empire building, but it also drove their "on the ground" representatives to participate in the race for empire as well.

Cresap and Gist's tendency to move "west" (or to the frontier, as Gist's first move to the Yadkin River Valley was south) in times of trouble was not unique. Cresap and Gist were among the many individuals and families who "fled" west after financial difficulties, partially because there was no alternative. Debts made it near impossible to pay rent or purchase land, whereas land and opportunity were in abundance in the backcountry. There was often no other choice but to flee civilization for the "frontier". Although both of these men may have moved west out of necessity, they also relocated to achieve upward mobility. Moving up in the (somewhat) established society of Baltimore was difficult. Cresap and Gist therefore looked to the edges of British settlement, where their skills were not only in demand but necessary. These important survival skills allowed them to occupy positions where they were able to succeed and make money; the Ohio Company of Virginia offered such opportunities. ${ }^{36}$

The fur trade, while a lucrative business, was not the major concern of the Ohio Company. However, it was a high priority for both Cresap and Gist. Both had ventured into

\footnotetext{
${ }^{36}$ Being "British" is a confusing state, for while they were certainly proud to be a part of the empire; the men investigated in this paper were not risking life and limb without assurances of reimbursement.
} 
the woods to pull money out of the streams by trapping and trading pelts. Their participation in this trade began their interactions with the Indians. For men such as Gist and Cresap, the fur trade was high on their priority list, partially because it was important to the Indians and hence Indian relations, and partially because both knew what fortunes could be made by such activity. Cresap and Gist were always interested in keeping their pocketbooks full, and they did not cease their trading activities while they were employed by the Ohio Company. Because this trade was important to the "action men" of the Ohio Company and the Indians with whom they traded, it ended up being important to the Virginia elites as well.

The early careers of both Cresap and Gist demonstrate what kind of background was required to work for the Ohio Company in the disputed Ohio territory. Along with having the ability to protect themselves from hostile Indians and Frenchmen, the Ohio Company required employees who could both navigate and survive in the "wilderness." These men also had to be able to communicate and properly trade with the Ohio Indians, as Indian trade was a fundamental aspect of the Company's cause. The Ohio Company did not simply select random traders; they chose men who had previously engaged in work for colonial powers. They needed motivated and ambitious men who were willing to take the risks necessary for empire building in order to augment their own fortunes. Cresap and Gist's backgrounds truly exhibit the criteria needed to successfully survive and work in the borderland.

Cresap was a Marylander. He served in a multitude of ways for Maryland's colonial government, but his biggest influence was on Virginia politics. During Cresap's brief period in Virginia, he became acquainted with many influential individuals and families, most importantly the Washington and Lee families. How Cresap, a debtor, came into contact with the Washington and Lee families is a mystery, but Cresap took full advantage of this chance 
meeting to aid his own circumstances. The relationships that were forged while Cresap was in Virginia would change not only Cresap's fate, but the fate of a continent as well. ${ }^{37}$

\section{Imperial and Independent Interests Intertwined}

In October of 1747 Thomas Cresap, Lawrence Washington and Thomas Lee gathered together to lay the plans for a company that would delve into the Appalachian Mountains and Ohio Country beyond, where they intended to build trading houses and create alliances. ${ }^{38}$ The Virginians believed that they had the right to expand due to the Treaty of Lancaster. This 1744 agreement was made between Virginia, Maryland and the Iroquois Confederation. The British were unable to keep their subjects east of the "Blue Ridge," which had previously been the agreed upon boundary. Negotiations took place at Lancaster, where the Virginians gave the Iroquois two hundred pounds of gold to give up their claim to the Shenandoah Valley. While this may have been the end of hostilities, misunderstandings prevented peace. The Iroquois believed they had just given up their claim to the Shenandoah Valley, while the Virginians were under the impression that they had just bought the rights to their entire charter, which extended to the pacific.

The Ohio Company, believing it had the right to the Ohio Valley, began making plans to erect settlements there. While Cresap was not responsible for securing the funding or obtaining the permission to carry out the plans for the Ohio Company's settlements, The Ohio Company was most likely his brainchild. ${ }^{39}$ Cresap had been corresponding with Lawrence Washington and Thomas Lee about the necessary measures that had to be taken in the Ohio

\footnotetext{
${ }^{37}$ Bailey, Kenneth, Thomas Cresap, Maryland Frontiersman (Boston: Christopher Publishing House, 1944) 31-36.

${ }^{38}$ Francis Jennings, Empire of Fortune. (New York, W.W. Norton Co.:1988) 8.

${ }^{39}$ Bailey, The Ohio Company, 25.
} 
Valley to secure it for Britain before the French could entrench themselves there. ${ }^{40}$ Cresap's contemporaries recognized his influence as well, although not always in flattering terms. In July of 1748, the Pennsylvanian Richard Peters commented that, "It was that vile fellow Cresap who had suggested the scheme to Colonel Lee and other great men in Virginia, to make trading houses at Alleghenny. ${ }^{, 41}$ Cresap saw himself as a man building both an empire and his personal fortune. He had already made a small amount of money by engaging in land speculation, and now with wealthy and influential backers, undoubtedly believed that he would be successful in building a large settler community in the Ohio Country, and in turn, achieving financial success.

The role of the Ohio Company in the story of British colonial expansion into the borderlands has been largely and wrongfully ignored in the historical literature. ${ }^{42}$ It was not the governments of Virginia, Maryland or Pennsylvania who pushed for exploration, settlement and fort building into and beyond the Appalachian Mountains (although a myriad of governmental officials were heavily involved in the speculation process). Rather it was the Ohio Company of Virginia, a private, commercial, non-governmental company that spurred Virginia westward. Although all members of the Ohio Company were already relatively wealthy (Cresap being the exception), they were interested in accumulating more money, land, power and influence. Land speculation and empire building were excellent ways to gain all of the aforementioned characteristics.

Land speculation in the British Empire was heavily depended on personal contacts, which was the reason that Cresap contacted Washington and Lee with his idea of the Ohio

\footnotetext{
${ }^{40}$ Bailey, The Ohio Company, 25.

${ }^{41}$ Bailey, The Ohio Company, 25.

${ }^{42}$ Samuel Wilson. The Ohio Company of Virginia 1748-1798, Lexington: Kentucky Law Review, 1926.
} 
Company. Due to the politics of monarchy, the patronage system endured and thrived in the British colonies. The different families and political groups gave out favors in order to achieve their goals. Because of this system, it was not uncommon to see governmental officials and their families benefiting commercially from governmental decisions, such as the Crown's decision to pursue expansionary practices. Although the Ohio Company did benefit from the patronage system, Crown's conections to the Company were even more binding than was usual for a land speculation company. As the next few sections demonstrate, there were times when it became impossible to discern where the British colonial government in Virginia stopped and the Ohio Company began.

The Ohio Company petitioned Virginia for a land grant in the Ohio Valley in 1747. The Company's grant had to be signed by the governor for the Company's settlement and other activities in the Ohio Valley to be legal. William Gooch, the governor of Virginia, was openly unfriendly towards the Ohio Company, and in an ironic twist of fate, it was Gooch's dislike of the Ohio Company that caused it to be one of the most influential imperial agencies in the colonies.

When the Ohio Company petitioned Virginia for a land grant in the Ohio Valley, (falsely) Gooch denied that he had the power to make such as grant. Gooch must have hoped that his inaction would end the Ohio Company's ambitions, but to the contrary the Ohio Company went over Gooch's head and sent a petition across the Atlantic to the Board of Trade. ${ }^{43}$ If Gooch had granted the petition, as was protocol, the grant never would have reached the Board of Trade, where (much to Gooch's displeasure) it was not only granted but also expanded. When the Board of Trade later questioned Gooch regarding his denial of the

\footnotetext{
${ }^{43}$ Kenneth Bailey, ed., The Ohio Company Papers, (Ann Arbor: Edwards Brothers, Inc, 1947) 47.
} 
Ohio Company proposal, he cited the fragile peace with France and his reluctance to take any action that might have caused conflict. Although a valid concern, this was not Gooch's true reason; he had vested interests with other companies, all of which had similar but less grandiose plans as the Ohio Company of Virginia.

By the time the Ohio Company sent its request to London in 1747, two other Virginia land speculation companies had petitioned the Virginia government for land grants in the Ohio Valley. Because the leaders of the Ohio Company knew that others were vying for similar grants, they embellished their petition to the Board of Trade with the language of empire. ${ }^{44}$ The Ohio Company's charter agent and representative in London, John Hanbury, who was also an Ohio Company member, made it clear to officials in London that the Ohio Company and the British Empire had similar views towards the situation in the Ohio region. ${ }^{45}$ He let it be known that the Ohio Company would promote British interests west of the Alleganies. The petition pointed out that the Ohio Company would add security and land to the British Empire. Hanbury's letters to the King pointed out that the Ohio Company would add to the British fur trade; and because the Ohio Company intended to "carry on a Trade with the Indians," the Ohio Company would erect a fortification in the Ohio Region that would "protect the infant settlements" already present in the British backcountry. ${ }^{46}$

\footnotetext{
${ }^{44}$ Bailey, ed., The Ohio Company Papers, 47.

${ }^{45}$ John Hanbury is not detailed in this paper, but it should be noted that he was a highly influential individual. He was the largest tobacco merchant of his time, which was probably how he came to be involved with the plans of the Virginia aristocracy. While he was the agent for the Ohio Company, he also was the agent for the College of William and Mary and the Loan Office of Maryland. He was also Parliament's agent to forward 10,000 Pounds annually to Virginia. His involvement most likely aided the Ohio Company in obtaining their land grant.

46 "Petition of John Hanbury to the King of the Behalf of the Ohio Company, 1748," in Bailey, The Ohio Company, 298.
} 
At first, the Ohio Company received no reply from the Board of Trade and Thomas Lee, being an ambitious man, was not inclined to sit back and wait for a delayed decision. He wrote letter after letter to the Board of Trade all of which explained the benefits of the Ohio Company. He wrote about the increasing threat of the "French intruders" and the danger of delaying action. ${ }^{47}$ Lee, of course, attempted to downplay his own interest and involvement in the Ohio Company, not mentioning how much he stood to gain from the success of the Ohio Company, but rather he stated that he had an intense desire to "extend the British Empire" ${ }^{48}$ Lee's use of imperial rhetoric seems to have worked, for the Board of Trade soon decided that the Ohio Company should receive its land grant.

In retrospect, the emphasized imperial nature of the charter, and the actions of John Hanbury and Thomas Lee may not have been necessary due to the aggressive nature of those on the Board of Trade. The Board's President, George Montagu Dunk, earl of Halifax, was eager to revive Britain's strong anti-French policies of the 1720's. Dunk, who was "hot for empire," according to historian Francis Jennings, thought the Ohio Company's plan to be a "proper step towards... checking the incroachments (sic) of the French." ${ }^{49}$ After the Board of Trade saw the original proposal, they drastically expanded the activities that the Ohio Company was required to do in order to fulfill the terms of their proposal. Halifax required the Company to build a settlement, place three hundred families there and build a fort for their protection. Those in London saw an opportunity to cement the claims of the British in the

\footnotetext{
47 Thomas Lee to the Board of Trade, September 29 1750, in Bailey, The Ohio Company, 303. ${ }^{48}$ Thomas Lee to the Board of Trade, October 2, 1749, in Bailey, The Ohio Company, 300. It seems that the Board of Trade was unusually busy during this time period, and that is why the Ohio Company petition took so long to be granted.

${ }^{49}$ Francis Jennings, Empire of Fortune, 12.
} 
Ohio Country while negating those of the French. Thus on March 16,1749, George II ordered Governor Gooch to issue the grant to the Ohio Company. ${ }^{50}$

Soon after Gooch's attempt to stop the Ohio Company in its tracks, the leadership of Virginia changed hands, and Thomas Lee, one of the three founders of the Ohio Company (and its real leader) was made acting Governor. This change, even if only temporary, allowed the Ohio Company to take action in the borderlands and recruit members. Robert Dinwiddie, a man in favor of both the Ohio Company and Virginia's westward expansion, became lieutenant governor. This change in administration demonstrates how blurred the separation of private and public spheres became in order to expand the dominion of the British. Governmental officials were suddenly important members of the Company and those who were members of the Company became governmental officials. The tangle of connections grew even worse as time went on; the Ohio Company employees were even given status and rank within the administration in order to ensure that the goals of the Company and Virginia were met.

Dinwiddie's membership in the Ohio Company is one of the reasons that the actions of the Company's agents become so confusing to historians and contemporaries alike. Dinwiddie held a number of shares in the Ohio Company of Virginia, and his business with the Company often became entangled with political and governmental affairs. Christopher Gist, the Ohio Company main employee, documentations that were used by Dinwiddie and other governmental officials. Gist's maps and descriptions did not stay in the hands of the Company, but became of part of the information that the British government would use as it attempted to claim the disputed territory.

\footnotetext{
${ }^{50}$ Bailey, The Ohio Company, 31.
} 
Apart from the confusion caused by Dinwiddie's political involvement in the private sphere, there is another puzzle. There is some debate in the historiography regarding the British government, Dinwiddie, and the Ohio Company. Specifically, it is the nature of Dinwiddie's membership that is called into question. Did he become a member before he was made governor, or after? According to Fred Anderson's book, The War That Made America, the Ohio Company "gifted" a large number of shares to Dinwiddie soon after he became the lieutenant governor. By doing so, Anderson argues, the Ohio Company ensured that their interests would be represented and protected from within the governmental structure. While this move would have been a clever one for the proprietors of the Company, an earlier historian argues that this was not the case. Kenneth Bailey, who devoted much of his career studying the Ohio Company, argues that Dinwiddie received the position as lieutenant governor because he was already a member of the Ohio Company. ${ }^{51}$ Bailey uses this evidence to show that the Crown was invested in the cause of the Ohio Company in the Ohio Country, and saw this as a way to ensure territorial expansion of the empire. To further complicate matters, Francis Jennings asserts that John Hanbury, the Ohio Company's agent in London, was so confident that the Ohio Company would succeed and prosper, that he managed to get Robert Dinwiddie and his own brother stock in the Ohio Company and then to additionally obtain the position of lieutenant governor for Dinwiddie.

Regardless of the details of Dinwiddie's appointment, he would go on to represent and promote the Ohio Company's interests. And despite the complicated process as to how he obtained the governorship, Dinwiddie was personally invested in the outcome of the Crown's actions and those of Virginia's sister colonies in the Ohio Valley. This is clear from his

\footnotetext{
${ }^{51}$ Kenneth Bailey, The Ohio Company, 31.
} 
correspondence. In a letter to Thomas Cresap, he stated, "I have the success of the Ohio Company at heart." ${ }^{, 52}$ It is clear that Dinwiddie used his office to advance the Ohio Company's cause. Even after Dinwiddie left office, and relocated back to England, he remained invested and active in Ohio Company affairs. Because of this, some may see the juxtaposing views of Bailey and Anderson as irrelevant, but this is not the case. The question, in this case, is more than just a slight distinction, for if Dinwiddie did receive the position of lieutenant governor because he was already a member of the Ohio Company, it significantly increases the importance of the Company in the eyes of the government in London, and it changes what London officials expected of Dinwiddie, the colony of Virginia, the Ohio Company, and the Ohio Company's agents.

Even before Robert Dinwiddie took the position of lieutenant governor, the Ohio Company was well entrenched in the Virginia government. There were many political elites on whose behalf Cresap and Gist were working, and many of them held positions in the colonial government. In addition to the governor, nine out of twenty Ohio Company members served on the Virginia Council, and two of these nine, at one point in time, served as president of the Council. The de facto leader of the Ohio Company, Thomas Lee, served as the acting governor before Dinwiddie's arrival, as previously mentioned. Lee's tenure as head of the Virginia government presents the difficulty of identifying distinctions between the private and public spheres. For example, he appointed Christopher Gist as an "official envoy" of Virginia before he took his first excursion into the Ohio Valley for the Ohio

\footnotetext{
52 Robert, Dinwiddie, The Official Records of Robert Dinwiddie, LieutenantGovernor of the Colony of Virginia, 1751-1758. The Collections of the Virginia Historical Society, ed. R. Brock. (Richmond: Virginia Historical Society)17-18.
} 
Company. ${ }^{53}$ As employees and envoys become one and the same, always representing more than one interest (their own, the colony's, the Company's and the Crown's), confusion ensued about who and what were in control of British fortunes in the Ohio Country.

This governmental interaction blurs the line separating for whom and what Gist and Cresap were working, especially since these officials did not hesitate to use political maneuvering and governmental resources to further the Ohio Company's cause. Because of this tangled situation, Cresap and Gist often found themselves working directly for the British Empire, as clear distinctions between the British Empire and private company eroded. For instance, while Thomas Lee served as acting governor of Virginia, he ordered Gist to begin exploring and surveying on behalf of Virginia and the Ohio Company. This is just one of many instances, but it shows how complementary the Crown and the Company were. Without this conflict of interest, Cresap and Gist would not have worked for the empire, they would have simply been independent traders, rather than part of the subtle inter-workings of the crown.

It is not only in retrospect that the relationship between the Ohio Company and the Virginia government becomes obvious. Henry Bouquet, in a letter to General Amherst regarding Thomas Cresap's attempts to persuade him to join the land speculation company, noted that he had been offered a chance to buy shares in the Ohio Company, which he called the "favorite Scheme of Virginia." formed an unofficial partnership to expand Virginia into the Ohio Country.

The previous section may lead one to think that Cresap, Gist and other Ohio company employees were not in the Ohio Country for their own personal gain; but they most definitely

\footnotetext{
53 Jennings, Empire of Fortune, 17.

${ }^{54}$ Lois Mulkearn, The George Mercer Papers, p.114.
} 
were. They had multipule and complex motives. Empire building has always gone hand-inhand with personal gain and private interests. Gist and Cresap were willing to carry out these tasks because their pocketbooks were fattened as a result, but it was crucial to their moneymaking endeavors that they had the crown's support. This is not to suggest that they did not care for the Empire, for they were proud of being a part of it and were interested in working and fighting for British imperial interests. The distinction here is rather like comparing a commissioned British solider and a mercenary; they both worked towards the same end and benefit personally, but their ideals and beliefs are the distinguishing factor.

The Ohio Company not only clashed with the French in the Ohio Valley, they also fought and completed with Pennsylvanians for the Indian trade. Virginia and Pennsylvania both maintained that they had rights to the Ohio Valley. Cresap and Gist were not the only Anglo-Americans adding to their wealth via actions in the Ohio Country; residents of other colonies also moved, traded and made a living in the Ohio Valley. The competition between various traders in the borderland led to hostility, especially in the early years of the Ohio Company. Although both the Virginians and Pennsylvanians coveted the benefits of the Indian trade, outside of this, their motivations and reasons for being in the Ohio Region were quite different. The Pennsylvanians just followed their Shawnee trading partners west.

The Shawnee Indians had lived in the Ohio region as late as 1600 , but the rising power of the Iroquois caused them to disperse. The Shawnees spread out all over the eastern part of America, especially in what are today the western parts of Pennsylvania and Maryland. When European movement in those areas increased and the Iroquois domination of the Ohio region lessened somewhat, some of the Shawnee moved back into the Ohio Valley. This 
westward movement of the Shawnee bands also brought the Pennsylvania traders westward as they followed their trading partners into the Ohio Valley.

These backwoodsmen were the closest geographic source of competition for the Ohio Company agents in the borderland. This inter-colonial struggle for dominance in the region would make the Ohio Country a borderland between colonies. Some may confuse these Pennsylvania traders as agents of empire, believing them to be similar to Cresap and Gist, but this would be a false assumption. The Pennsylvanians who had been trading with the Indians merely drifted, following their trading partners west to their new location. The Pennsylvania traders were not exploring or trying to expand the British Empire. Thus, they were concerned solely with private interests.

The difference between the two groups was not lost upon their trading partners; the Indians recognized the difference between independent traders and those representing the Ohio Company. The Indians who lived in the Ohio Valley had swift channels of communication. Through these channels, news about the Ohio Company and its intentions were able to permeate the Appalachian Mountains. ${ }^{55}$ The Indians living in the Ohio Valley did not see a great threat in the Pennsylvania traders, who carted coveted bolts of fabric, mirrors and guns into the Ohio, and then vacated the area to return later with more trade goods. Indeed, these Pennsylvania traders were almost universally welcomed. The Indians also welcomed the Ohio Company employees (and their cheaper prices, which most of the

\footnotetext{
${ }^{55}$ As the conflict between the French and British became imminent, Pennsylvanians did work for the British as interpreters and scouts. After the initial explorations of the Ohio Company, many prominent Pennsylvanians, such as "the Prince of Pennsylvania", George Croghan, came to be under its employ. However, it is important for scholars of the borderland and intercolonial competition to know that Conrad Weiser, a trader and loyal Pennsylvanian, would not agree to work for the Ohio Company.
} 
time undercut the Pennsylvanians), until they showed up with messages from the King and ambitions to claim and settle the land. ${ }^{56}$

The Ohio Company's intentions to settle the land and represent the King are essential to understanding the difference between the Pennsylvania traders and the employees of the Ohio Company. Cresap, Gist, and others on the Ohio Company payroll sought to extend British settlement into the Ohio Valley, whereas the Pennsylvania traders had no such grand plans. The Pennsylvanians were not trying to make gains for the Crown or attempting to erect a permanent settlement; instead, most tried to thwart the Ohio Company's efforts to do so. ${ }^{57}$ The following example, which is explained in greater detail in the second chapter of this work, shows the indifference of the Pennsylvania traders to the Ohio Company's attempts to expand the British Empire. In 1752, the Ohio Company, in partnership with Virginians, held a conference at Logstown to gain permission from the Indians of the Ohio Valley to erect a settlement at the Three Rivers, later Pittsburgh Pennsylvania. Dinwiddie had petitioned the Governor of Pennsylvania to partake in the conference as well, but he declined, however he sent a delegate (in the form of George Croghan) to ensure that the Indians knew that Virginia had the support of the Pennsylvanians. ${ }^{58}$ Some Pennsylvania traders disobeyed their governor, and attempted to ruin the Logstown conference, the objective of which was to expand the British Empire or the influence of the Virginia government. This conference was an important step (in the Eurocentric view) in Indian-Anglo negotiations. The Pennsylvania

\footnotetext{
${ }^{56}$ It is important to note that the Ohio Company was able to offer European goods at cheaper costs because their ultimate goal was not to make a profit from the Indian trade. Trading with the Indians was a preliminary step to establishing settlements in the Ohio Country.

${ }^{57}$ Fred Anderson, The War that Made America, (New York: Viking, 2005) 27.

${ }^{58}$ George Mercer, The George Mercer Papers, 243.
} 
traders were less committed to the conference because they were not interested in erecting British settlements or extending the empire beyond their own trade.

One reason for hostilities between the two groups was the Ohio Company's low trade prices. They were able to offer lower rates because Christopher Gist found a shorter, easier route through Virginia to the Ohio Valley that made the westward journey more costeffective. This new trading path as well as their ability to subsidize goods meant that they could offer lower prices to the Ohio Indians. The Ohio Company traders were able to offer subsidized goods because they were not interested in the profits of trade, they were interested in maintaining friendly relations with the Ohio Indians so they could eventually erect settlements and trading posts in the disputed territory.

The Pennsylvanians, furious over the Ohio Company's trade practices, did not stop their propaganda war in the borderlands simply because the Pennsylvania governor had ordered them to. The Pennsylvanians made sure to alert the Europeans living in western settlements to the dangers the Ohio Company's policies. They asserted that the Company's fort would be a "bridle" on the Indians. ${ }^{59}$ They also were in opposition to the Ohio Company's proposed roads, which they claimed would be used by their western enemies (both French and Indian) to destroy their settlements. ${ }^{60}$ Despite the best efforts of Thomas Lee and other Ohio Company leaders, there was little they could do to stop the Pennsylvanian's antagonistic rhetoric.

It is not difficult to pinpoint instances of disagreement or hostility between Pennsylvania traders and the Ohio Company representatives. However, this rivalry seems not to have amounted in much documented physical conflict. For historians, this dispute mainly

\footnotetext{
${ }^{59}$ Bailey, The Ohio Company, 112.

${ }^{60}$ Bailey, The Ohio Company, 113.
} 
manifests itself in the form of political rhetoric between Virginia's interim governor, Colonel Thomas Lee, his successor, Robert Dinwiddie, and Pennsylvania's governor, James Hamilton. ${ }^{61}$ Many letters were exchanged between Williamsburg and Philadelphia regarding the Indian trade and the conduct of those who were engaged in the said trade. Both of Virginia's governors, highly invested in the situation as Ohio Company stockholders, were inclined to the blame the Pennsylvanians for the disputes. While Hamilton supported the colonists from his region, it was difficult when the Ohio Company had a royal charter instructing them to engage in Indian trade. Hamilton, however, did not do much to reign in the traders from his colony. When Lee protested and suggested that the offending traders be locked up, Hamilton replied that none of the traders in question were in the city at the moment: in reality, he did little to look for them. ${ }^{62}$

While both of these colonies were part of the British Empire and were proud of that distinction, they often had competing interests. Governors frequently complained about one colony's infringement on another, and very rarely did colonies cooperate or act in unity. It had only been a few years since Maryland and Pennsylvania had fought over land, and the conflict had only ended when the King intervened to finalize the boundary. No "American Consciousness" had formed by this point, as colonies saw themselves as different and separate, and often in competition with one another.

Although the rivalry between Pennsylvanians and the Ohio Company was plain to anyone living in the British colonies, it was not so apparent to the French. The French, giving the British more credit than they deserved, believed the Ohio Company representatives and the Pennsylvania traders to be a two-prong invasion into the disputed territory. The

\footnotetext{
${ }^{61}$ Bailey, The Ohio Company, 113.

${ }^{62}$ Bailey, The Ohio Company, 112.
} 
combination of the Ohio Company and the Pennsylvania traders was enough to spur the French into action involving La Belle Riviere. ${ }^{63}$

The French viewed the British traders as trespassers due to the claims of early French explorers such as La Salle who had paddled the waters of the Ohio spreading the Catholic faith and the French flag. When the French heard about the motives of the Ohio Company, they were forced to take counter actions of their own. A Frenchman known as Céleron was instructed to travel the entire Ohio Country to further the claims of the French. Céleron and the three hundred Frenchmen he led placed seven lead plates at key strategic locations along the Ohio and its tributaries to expressly show ownership of the area. The British and Indians, of course, did not view the French claim as legal or valid. It is obvious that the British did not think so, for they paid no heed to the French claims. They continued to travel as they pleased and sent their own agents to mark the Ohio River Valley as British.

Iroquois actions do not demonstrate that they respected the French claim any more than the British: in fact they were angered that the French would lay physical claim to land they considered under their dominion. An Iroquois warrior, for example, surreptitiously pulled one of the lead plates from the earth and ran with it back to Onondaga. ${ }^{64}$ This trip of several hundred miles by the Indian runner was well worth the effort because the Iroquois Confederation Council's actions reverberated throughout their "empire." While Céleron was burying the plates, he crossed paths with a few British colonists, and while he warned them that they were trespassing on the lands of Louis XV, he was aware that without subsidized trade goods and permanent trading stations in the Ohio, the French would not be able to keep

\footnotetext{
${ }^{63}$ The French name for the Ohio Valley, which meant "the beautiful river." ${ }^{64}$ Christopher Gist's Journals. 28
} 
the British at bay. The Ohio Company of Virginia pushed all of these issues, making tFrench claims on the contested land, more uncertain than ever before.

The lead plates were just the beginning of increased French activity in the Ohio region. Despite the fact that Canada had "always been a burden to France," they were intent on protecting their claims to the disputed land. ${ }^{65}$ Marquis La Galissoniere insisted that the French needed the "strongest barrier...to the ambitions to the British" and that "honor, glory and religion forbade its abandonment." ${ }^{, 66}$ After Céleron had departed on his excursion, the Marquis was recalled to France, where he told the French Court that they needed to take measures to strengthen their position at Fort St. Frederic, and at the posts of Niagara, Detroit and the Illinois. The court followed his advice, and began implementing measures that would offset the actions of the Ohio Company, and further worry the already tense Iroquois and Ohio Indians.

The real reason the French were aggravated about the Ohio Territory was because of the actual British movement within the region. The Ohio Company and all of its imperial connections would not have bothered the French if Thomas Cresap and Christopher Gist had not been active in the Ohio Valley. Cresap and Gist moved the British Empire beyond mere claims and towards actual occupation. Of course, all of Cresap's and Gist's actions (that are detailed in the next chapter) would not have actually expanded the British Empire if they had acted without the support and permission of the colonial government and those officials in London.

${ }^{65}$ La Galissoniere, Memoire, Dec. 1750, Documents for the Study of American History, http://www.vlib.us/amdocs/texts/galissonierre.html.

${ }^{66}$ La Galissoniere, Memoire, Dec. 1750 


\section{Chapter Three}

On the Ground Agents

"He has been and still shall be ready on all Occasions to risk his Life, and small fortune in promoting the settlement of that part of his Majesty's Dominions, so necessary to the Preservation and Interest of all his American Plantations."

\section{Christopher Gist}

Gist wrote these words in application for compensation from the Crown for the destruction of his property that had been destroyed by pro-French Indians at the start of the Seven Years' War. While his claim was denied, Gist's plea for compensation demonstrates that both he and Cresap knew their self-promoting actions complemented the interests of the British Crown. Gist was true to his word, as the next section demonstrates, for he was willing to "risk his Life," as was Cresap, as they worked for the Ohio Company of Virginia in order to expand British claims in North America.

Although chapter one details the vast number of imperial and governmental connections that bound Cresap and Gist to the British Empire, these connections meant very little if actions were not carried out. This chapter details the "on the ground" actions of Cresap and Gist in the Ohio Country. Their actions as traders, diplomats, surveyors and builders are scrutinized. This chapter begins with a description of Cresap's roles and responsibilities. That discussion is followed by a survey of Gist's contributions. This section concludes with reviews Cresap and Gist's joint efforts for the Ohio Company of Virgingia.

To those studying Atlantic history, Cresap's and Gist's imperial connections mean everything, to the tribes with whom Cresap and Gist traded and negotiated, they meant very ${ }^{67}$ Bailey, Christopher Gist, 156. 
little. The headmen did not ask for specifics on the nature of these white men's relationship to the Crown. They did not ask to see the Ohio Company's proposal or correspondence from London. The Ohio Indians were more concerned with what goods the Ohio Company agents offered. But to a few, like Tanaghrisson and Old Briton, where they came from and whom they represented meant everything.

Those men who send the goods to the Ohio Indians were ambitious men; it is not surprising therefore, that they began the push westward before they actually received official permission from the Board of Trade. Thomas Lee's westward movement was without choice; by the time that he was able to obtain Gist's services, both Pennsylvania and France had heard of the Ohio Company's plans and were already planning their own responses. Gooch's refusal forced the Ohio Company to slow its movements into the Ohio Valley and gave Company competitors time to catch up. Because they had not yet heard from the Board of Trade, the Company was forced to take more conservative measures as they attempted to ensure future success. They engaged in the Indian trade, fur trapping, and preliminary exploring excursions. The Company also erected a new trading house at Wills Creek, near present day Cumberland, Maryland, that would serve as a base for the Company's endeavors until they could build one in the Ohio Region.

The only reason that the Ohio Company was able to successfully carry out any preliminary measures was due to Cresap's involvement. Cresap's previous endeavors on the edge of the British Empire made him an important resource to Thomas Lee and Lawrence Washington as they served in their capacity as leaders of the Ohio Company. Cresap possessed knowledge of the area that the Ohio Company wanted to explore and settle, and he 
knew the customs and trade habits of the Indians who lived in the Ohio Valley. ${ }^{68}$ Because of these attributes, Cresap played a significant part of the planning and organization process. As important as Cresap was to the affairs of the Ohio Company and to the situation in the Ohio Country, it is important to mark the limits of his initial influence over other members of the Company. While Cresap possessed a few tracts of land in western Maryland by the time the Ohio Company formed, he was not part of the "landed gentry" or the Virginia aristocracy. A close study of the Virginians involved makes the Ohio Company appear to be something of a family reunion. There were multiple connections between the Lee, Washington, Mercer, Mason and Fairfax families, as well as many others, either through blood or marriage.

Cresap's lack of wealth and "noble" blood, as well as his status as a Marylander, caused other members to ignore his advice and knowledge. As time went on, however, his advice became respected and coveted and his knowledge, courage and wily nature more than made up for his lack of "blueblood."69 Cresap's influence grew even more after the untimely death of Thomas Lee, for as Kenneth Bailey argues, “Thomas Cresap was probably the most important member of the Company after the death of Thomas Lee."70 While this assertion remains debatable, Cresap was the member with the most first-hand information and knowledge of the area in which the Ohio Company wanted to expand. ${ }^{71}$ He was the resident expert on Indian affairs in the Ohio Valley, especially with the Iroquois, since he had lived and traded in such close quarters with them in Oldtown. He was also close with many of the Indians who made

\footnotetext{
${ }^{68}$ Thomas Lee and Lawrence Washington were both familiar with the Ohio Country, but not to the extent of Cresap.

${ }^{69}$ Although most of the members of the Ohio Company came to respect Thomas Cresap and valued his usefulness, they were not necessarily fond of him.

${ }^{70}$ Bailey, The Ohio Company, 47.

${ }^{71}$ If Thomas Lee had lived, the story of the Ohio Company would be very different. They would most likely been more successful and active, and the Ohio Company's story would not be so anticlimactic.
} 
their homes near his fortified home; most obvious was his relationship with Nemacolin, a Delaware man, with whom Cresap and his sons frequently traveled. Because Cresap possessed knowledge of the Indians and was able to engage in the proper rituals and customs, Cresap was the advisor in most situations regarding Indian diplomacy.

\section{Thomas Cresap: Indian Ambassador}

Due to their prior knowledge of Indians, it is not surprising that both Cresap and Gist were a part of the complex and polycentric communication network that spanned the Atlantic Ocean and half of North America. While France and Britain constantly watched, spied and engaged in direct conversation with one another in Europe, this was not possible in the "New World." Cresap and Gist, as well as other agents of empire, were the only means of investigation; they were the eyes and ears of the British.

Cresap and Gist spied and gathered information to pass on to London, while giving the Indians information to pass on to their French counterparts. Due to the nature of this unstable information network, Cresap and Gist kept the British government aware of activities or encroachment into the Ohio Country. Without such scouting expeditions, the French could have done as they wished without British competition. The men who worked and spied in the Ohio Country were necessary for trans-Atlantic communication. ${ }^{72}$

This communication network and the presence of Indians in the Ohio Country made others in the Company reliant on Cresap. One of Cresap's main contributions to the Empire and the company was as an advisor to Governor Dinwiddie. Cresap instructed various

\footnotetext{
72 The Indians are possibly the most important link in the information pathway, for they could manipulate the information to suit their purposes; this is the nature of borderland circumstances.
} 
members of the Ohio Company on how to act in various situations when dealing with the Indians and kept the Governor updated on the progress (or lack thereof) in the Ohio Region. Dinwiddie noted in January of 1752 in a letter to Cresap that they (Dinwiddie and Cresap) were to be the only members of the Ohio Company who appeared concerned about the fate of the Company or about the worsening Indian relations in the region. ${ }^{73}$ This letter, while very short, is informative. First, it demonstrates that most of the members were not physically involved in the tasks that needed to be completed for the Ohio Company to attain its goals. Most of the members were unaware or unconcerned with the day-to-day activities of the Company's employees. It was left to men like Cresap and Gist to take action and take care of the "on the ground" progress for the Ohio Company. Secondly, this letter shows the role that Cresap played in the information gathering that took place regarding Indians and the backcountry. He was the one who communicated the backwoods situation to the principal members of the Ohio Company who in turn would communicate this to the officials in Virginia and London.

When Thomas Lee became the acting governor of Virginia, the Ohio Company took its first steps towards expansion into the Ohio Region. Before they had even heard from the Board of Trade with an affirmative answer, they took action. Since they could not actually occupy the Ohio Valley, they moved right to its border. The Ohio Company, Thomas Cresap, and one of the lesser employees of the Ohio Company, Hugh Parker, attained land from Lord Fairfax. This land was not unknown to Cresap, as he had surveyed it earlier in his career for Maryland's Governor, Thomas Bladen. He had previously called the place "Wills Town,"

${ }^{73}$ Letter to Thomas Cresap from Robert Dinwiddie, 1752, Bailey, The Ohio Company, 193. 
because the land surrounded Wills Creek. ${ }^{74}$ The area was also called "the Forks" due to the fact that it is where Wills Creek joined with the Potomac River. The Ohio Company had plans for this land, and surveyed both sides of the river and planned a town. ${ }^{75}$ Before the town could be built, however, they first had to erect a trading post. This job was left to Thomas Cresap's right hand man, Hugh Parker. Parker built a two-story log trading post that stood on the Virginia (today West Virginia) side of the Potomac, directly across from where Wills Creek emptied into the Potomac. The Ohio Company's structure attracted trappers due to its strategic location for it was situated along one of the quickest and easiest ways west. Some traders, who would have otherwise not been involved with the Ohio Company, became involved in the maintenance of the post and began trading for the Ohio Company because of the location Cresap had chosen.

The Ohio Company thrived at Cresap's well-chosen location, for in 1752, they built another, larger and more impressive structure next to the first. This structure was built not only to hold European trade goods and Indian furs, but also to house the traders themselves. Another reason for its impressive size was that the structure served as a defensive refuge in case of an attack by the Indians. The Indians, despite being provided with cheap goods by the Ohio Company, were not pleased by their continued and hasty movement west. They sometimes acted against the Ohio Company and occasionally attempted to stop their progress

\footnotetext{
${ }^{74}$ The spelling of "Wills" as it relates to the town and the creek varies depending on the author. It is spelled "Will's" or "Wills" "Wills" is the term used in this paper unless employing a direct quotation.

${ }^{75}$ The site that Cresap and Parker choose continued to be a transportation and trade hub into the twenty-first century. The National Road, the Chesapeake and Ohio Canal, Route 40, Interstate 68, as well as the Baltimore and Ohio Rail Road, the Western Maryland Rail Road and the Chesapeake and Pennsylvania Railroad (all of which today are a part of CSX transportation) all pass through Cumberland, Maryland, which is the modern city that stands on the banks of the Potomac and Wills Creek.
} 
in the disputed land. The more fortified structure at Wills Creek was therefore necessary for the trader's safety.

Once the Board of Trade approved their proposal and gave permission for the Ohio Company to erect a settlement into the Ohio Valley, they had to carry out three provisions in order to validate their grant in the Ohio Valley. One proviso stipulated that they had to build a settlement and place three hundred families there. This meant they had to find, obtain, and then survey the land on which they planned to build a settlement. The Ohio Company agents were also responsible for finding families to settle this land, and then persuading them to actually make the move west and purchase land from the Ohio Company. The Board of Trade also dictated that the Ohio Company had to build two forts in the disputed territory. ${ }^{76}$ Again, this meant the Company had to find the land, obtain the consent of the Indians living in the area, and then build the actual fort. Finally, the Ohio Company was to engage in trade with the Indians present in the Ohio River Valley. Although no documents explicitly state that the provisions in the Ohio Company's proposal were added to aggravate the French traders, they certainly served that purpose.

The Board of Trade's mandates were not the type that the Virginia elites, who were the Ohio Company members, were going to carrying out themselves; instead, they relied on others to carry out the directions of the Board of Trade. Even those "gentlemen" with a good deal of knowledge about the situation in the disputed territory, particularly Lawrence Washington and Thomas Lee, did not travel into the wilderness to deal with Indians, trap beaver, and combat the elements. It was Thomas Cresap, Christopher Gist and a few other employees who actually carried out the provisions of the Company’s grant. Without them,

\footnotetext{
${ }^{76}$ The Council to the Ohio Company, Bailey, The Ohio Company of Virginia, 205.
} 
the Ohio Company would have had little influence in the Ohio Country. The best ideas and intentions of those elites in the eastern part of the country would have amounted to nothing if not carried out by their employees.

Gist's diaries detail the dangers as well as the brutal weather encountered by those who worked in the Alleghany Mountains. ${ }^{77}$ Gist exposed himself and his son to the elements; they both experienced frostbite on their hands and feet. ${ }^{78}$ Those who undertook such risky and unpleasant missions had to have something substantial to gain. Those who resided in large plantation mansions and ate exotic food did not have the same motivations as those who lived in log cabins and lived off venison. Gist tried to pay his never-ceasing debt and establish a new home. Cresap attempted to break his cycle of debt and westward movement by finally becoming stable enough to live in one place for more than a few years. These men had the motivation to undertake the unpleasant tasks that were required of those "on the ground" empire builders. While the Ohio Company investors risked a bit of their money on Ohio land speculation they did not risk life and limb. Instead they found those who were desperate or ambitious enough to attempt to make a living on the frontier.

Fortunately for the Ohio Company, they had one of these desperate men right in their midst. Thomas Lee, who at the time was the de facto leader of the Ohio Company and the Virginia government, instructed Thomas Cresap to explore and then survey the little known Ohio region. In 1749, Thomas Cresap set out for the Ohio Valley and looked for a site that would be suitable for the Ohio Company fort or the settlement of the three hundred families.

\footnotetext{
${ }^{77}$ George Washington was not at this time the elite planter that he was to become. At this point in time he was the third son of a failing plantation owner who looked to a military career for social and financial success.

${ }^{78}$ George Washington, The Journal of Major George Washington, (Williamsburg: The Colonial Williamsburg Foundation, 1982) 22.
} 
Cresap was unsuccessful in choosing a site. Historian Kenneth Bailey says little about Cresap's failure, except for citing the fact that he was a trader, not a surveyor. Upon a closer study of Cresap, this is proven incorrect, for even in Bailey's own biography on Thomas, he cites many occasions when he was sent by the colony of Maryland, Dinwiddie, and the Ohio Company to survey lands. More likely, Cresap's failure was due to a combination of Indian hostilities and Pennsylvania opposition to his presence in the Ohio. Upon Cresap's return, Thomas Lee sent Christopher Gist, at the suggestion of Thomas Cresap, into the Ohio region.

Since two of the three provisos of the Board of Trade grant - the fort and the settlement - were dependent upon the outcome of Gist's explorations, the Ohio Company was left to focus on the Indian trade. Thomas Lee had informed officials in London that the success of this commercial enterprise was vital to Britain's victory in the disputed territory. It was this determination to trade that would cause hostilities between the Virginians and the Pennsylvania traders. Besides the settlement at Will's Creek, which was built to better trade with the Indians, the establishment of Virginia in Indian trade was the only thing the Ohio Company accomplished prior to their hearing an affirmative decisions from the Board of Trade. The Ohio Company wanted to begin trade right way, but first they needed actual traders. With Gist in unknown lands, the Ohio Company turned to Thomas Cresap. The Company gave Cresap free rein to hire the traders he thought best, and that is how some Pennsylvanians came to be under the employment of the Virginia based company. It was times like these when it became evident that having Cresap in the Ohio Company of Virginia paid off, even if he was not a polished aristocrat like the rest of the members. The Virginia planters would have been lost without him, as they did not know who was an adequate trader or which "frontiersmen" were fair, able and capable of maintaining good relations with the 
Indians. Without their employees, the Ohio Company would not have been able to carry out the provisions that the Board of Trade had specified in their proposed land grant, and it could be argued that it was commercial actions like these that truly built the British Empire in the Ohio Region.

Hugh Parker was one of the "frontiersmen" that Cresap employed and he soon became his right hand man as he carried out Ohio Company business. Parker and Cresap traveled around the backcountry and spread the word that it was better to trade with the Ohio Company than anyone else. The Indians did receive better prices from the Ohio Company, and some began to exclusively trade with them. It was these men and their cheap goods that worried the Pennsylvanians and influenced them to take further steps to secure the Ohio Country for their own colony. The following example demonstrates Cresap's attempts to undermine the Pennsylvanians. On July 7 1749, the Pennsylvanian Indian Supervisor, Richard Peters, held a trade conference with a few bands of Indians at George Croghan's home in Pennsboro. Not long into the negotiations, a Seneca man arrived and reported that an Ohio Company trader, Barney Curran (hired by Cresap), had carried a message from Thomas Cresap that suggested that he would willingly trade with the Indians using rates cheaper than the Pennsylvanians were willing to offer. ${ }^{79}$ It was at this time that Peters blamed Virginia's new activity in the borderlands on Cresap, whom he called "that Vile fellow." 80

The Indian trade, however, was not the end all goal of the Ohio Company. When the Ohio Company petitioned the King of England for a land grant, they intended to settle one hundred families on the land requested. The Board of Trade agreed to allow them to settle families on the land in order to secure its possession for the British, but they increased the

\footnotetext{
${ }^{79}$ Bailey, The Ohio Company, 24.

${ }^{80}$ Bailey, The Ohio Company, 25.
} 
acreage allotted to the Ohio Company and increased the number of families to three hundred. This settlement, however, became a source of contention between the Ohio Company and the Indians. Thomas Cresap, the chief Indian agent for the Ohio Company, earlier told the Ohio Indians that they would be able to purchase cheaper goods from the Ohio Company than from their rivals, the Pennsylvanians. The Indians, who were pleased to hear this, failed to understand that the cheap goods came with a high price: an English settlement in the Ohio Valley. Thomas Cresap unsuccessfully negotiated with the Indians in order to fill the Ohio Company's lands with settlers. If he had been successful, the settlement would have enlarged both the pocketbooks of the members and the territory firmly within the grasp of the British. Of course, this idea and the actions leading up to its creation alienated the Ohio Country Indians, for as much as they wanted better trading prices, they did not want British settlers pouring into their lands. Cresap's actions caused some of the Ohio Indians to turn to their other European neighbor in the Ohio Valley, the French. These Indians wasted no time in telling the French of the plans of the British to plant families in French territory. The information pathway between the French located in the interior of the continent and that of the British creeping further inwards was one made up of Native Americans. The French were alarmed to hear that three hundred British families were coming to live and trade in lands they considered to be part of New France.

While other members of the Ohio Company were not active in the Ohio Country, it is obvious that this was not the case with Cresap. He, and the lesser employees of the Ohio Company, represented the Ohio Company to the Indians of the region. Cresap was the one with whom the Indians associated during the exchange of trade goods and throughout diplomatic proceedings. As has been pointed out, one of the reasons Cresap was a highly 
valuable member of the Ohio Company was his acquaintance with others who had similar lifestyles to his own. Due to the location of his home and fort at Oldtown, he was able to identify almost any white settler or trader that could be found in the Ohio Valley. It was through these connections that the Ohio Company gained many of their employees, such as William Trent and Hugh Parker. The most important recommendation made by Cresap to the Ohio Company was the employment of Christopher Gist.

By the time Christopher Gist moved into the Yadkin River Valley, he was known as a great surveyor and voyager. "As an explorer he was unsurpassed in colonial times," Kenneth Bailey asserts in his history of the Ohio Company of Virginia. ${ }^{81}$ When considering all of the famous colonial explorers, this is high praise indeed. But Gist did more than just explore. While he was in the Ohio Country, he acted as an unofficial British ambassador and diplomat, by giving gifts and relaying messages from the King of England to the Indians who lived near the headwaters of the Ohio River. Gist's overarching goal was to find a way for the Ohio Company to expand their activities into the Ohio Country. The Ohio Company needed to move beyond trading and exploring in order to meet the requirements of their land grant. Their main goal was to build a "strong house" at the forks of the Ohio River. In order to erect such a structure, they would have to make an agreement with the native inhabitants of the Ohio Valley. Gist's relationships and agreements with the Ohio Indians were key in ensuring that the Ohio Company's goals would be met. Cooperation with local Indians was essential to the Ohio Company achieving success in the disputed territory.

Gist's accounts show that he pursued Anglo-Indian relations and trade, and created and maintained allegiances with the Native Americans, but Gist's main concern was land, not

${ }^{81}$ Bailey, The Ohio Company, 86. 
people. He looked for the best land in the Ohio Country to recommend to the Ohio Company, whose land grant did not have a specific set of coordinates. Gist had to be covert as he scouted and surveyed the land. The Indians would naturally be against British expansion into lands they considered their own. Not only did Gist want to forge alliances with the Indians, he also did not want them to tell the French that the British planned to erect settlements in the disputed territory. Gist was careful not to let any Indians see a compass, partially due to their superstitions and partially because those Indians who were familiar with European technology were wary, as they saw the compass as first step towards white settlement. ${ }^{82}$

Other Virginia traders (Cresap and Parker) had been unsuccessful in the territory, but Gist completed two separate trips into the Ohio River Valley. The primary material on Cresap and Gist shows the reason for these differing results was personality. Cresap was known as a hot head, quick to anger and throw punches: there was a reason he was known as the "Maryland Monster." Gist was known to be more mannerly, able to keep cool in tense situations and overcome personal insults to achieve his ultimate goal. Of course, the two men had not operated in identical circumstances, and that may have been part of the difference, but the fact remains that some Anglo-American colonists did not hold Cresap in high esteem, where as Gist was well-liked, respected and known among Indians and Europeans as a fair trader. His personality traits were important to the diplomatic functions in which he was serving. In his travels over such a large territory, Gist could have come in contact with twenty different dialects. Learning some or any of these linguistic variations would have taken an unusual amount of intellect. Gist's ability to communicate with the Indians may have been key in his success in the Ohio country.

\footnotetext{
${ }^{82}$ Powell, Forgotten Hero's, 10.
} 
Gist's very presence, let alone the Ohio Company's intended settlement, was "trespassing" in the eyes of other Europeans. The French knew via the Indian communication lines that Gist had interacted, traded, and negotiated with the Indians on lands the French claimed as their own. These were the same Indians the French wanted to sway towards the French cause. Gist's activities deep in the Ohio Country acted as a catalyst for the French to increase their own efforts to claim the Ohio, especially through Indian negotiations, since these parleys were the most inexpensive means of empire building. In essence, when Lee sent Gist deep into the disputed territory, he started the "arms race" in the borderland between France and Britain that continued to escalate until war erupted in 1754.

The Ohio Company gave Gist his instructions on September 11, 1750. He was to go west to the "Falls of the Ohio," note the passes through the mountains, and observe the course of the rivers. ${ }^{83}$ The Ohio Company wanted to ensure that once they found the land for their settlement, they would be able to get the settlers and their trade goods there without difficulty. Most importantly, Gist was to be on the lookout for any fertile lands that would be suitable for settlement and farming. ${ }^{84}$ When he found these lands, he was to survey and measure them in a number of ways and from different points, so the Ohio Company could find and identify them without a problem. The Company officials dictated that even if Christopher Gist were to find suitable land for an Ohio Company settlement before he reached the falls of the Ohio, he was to continue to the source in order to report on navigation possibilities. In addition to his other duties, Gist was also on a reconnaissance mission. He was to observe the Indian strength and numbers, as well as the location of their settlements and hunting grounds. In order to understand and further benefit from the Indian trade, Gist was also instructed to find

\footnotetext{
${ }_{83}^{83}$ Christopher Gist's Journals, 65.

${ }^{84}$ Christopher Gist's Journals, 65.
} 
out with whom the Indians traded and what types of goods were most coveted by which bands.

Gist's subsequent reports to Dinwiddie, other Ohio Company members, and the Board of Trade must have been tantalizing. If it had not been for Gist's promising descriptions, the attempts to settle the backcountry may have been abandoned, especially since doing so would likely spur international conflict. Gist told of lush river bottoms, "white oak forests," fertile valleys and immense salt licks. ${ }^{85}$ His journals gave those persons "back east" a picture of what the British Empire could attain and what the Empire would look like if the Union Jack flew over the Ohio country.

Throughout Gist's journals, he did not promote the "Ohio Company" or "Virginia" but instead the "British" and the "King." "86 Gist wrote in this manner knowing that his employers, the Ohio Company, would read his journal and other records he created while on his excursion. He did not seem to think that representing himself as an ambassador of the King of England, would upset his employer Ohio Company of Virginia. Apparently the British officials as well as the Company officials were fine with Gist and other Ohio Company traders representing themselves as British. Their lack of protest shows the Ohio Company and the British Empire were closely linked. They did not protest Gist's interchange, which indicates that they may have been unable or unwilling to distinguish where the British government stopped and where the Ohio Company began.

Gist's identification as a "Briton" was important, for while Gist's main goal was not diplomatic, the many negotiations he held to arbitrate with Indian leaders ended up being the most important function of his mission. The relationships he forged with these headman and

\footnotetext{
${ }^{85}$ Christopher Gist's Journals, 66.

${ }^{86}$ Christopher Gist's Journals, 66.
} 
their people were highly important to the success of the British cause in the borderlands. The Indians, may have been wary, but they still viewed him as a British representative. To presume that the Ohio Indians trusted Gist is valid. Gist highly pleased the Indians, according to his own reports, for he was "adopted" by one band and given the name Annosanah (although he respectfully declined their offer of permanent residence at their village). ${ }^{87}$ "Annosanah" was apparently the name of an Indian who had recently died in this village; the best translation that is found in any primary or secondary sources is "good man." ${ }^{, 88}$ At this same village, he gave a short sermon that outlined Christian principals, and some of the Indians, after listening to Gist, claimed to be converted.$^{89}$ Gist noted that these individuals might not have taken Christianity or their baptisms all that seriously however, because the next day these same men stoned members of their tribe to death. ${ }^{90}$

Gist's various roles as trader, trapper, missionary and diplomat often seem intertwined, but other times seem to be opposed. Understanding the intent of Gist's mission is easier if it is explained from the beginning. The next section details his two excursions into the Ohio Country, starting at the base of Ohio Company operations in Oldtown, which is where he began his journal. Christopher Gist left Cresap's home on October 31, 1750 and made a twenty-two day journey to Shannopin's Town, which is near present day Pittsburgh. Here Gist ran into his first bit of trouble. The Indians were suspicious of him, as they were of many Europeans, and were about to kill him when Gist overheard the Indians talking and discovered that George Croghan was in the area. Gist "name dropped," claiming that he was

${ }^{87}$ Christopher Gist's Journals, 38.

${ }^{88}$ Christopher Gist's Journals, 38.

${ }^{89}$ Christopher Gist's Journals, 38.

${ }^{90}$ Christopher Gist's Journals, 38. Gist's observations about the Indians stoning shed light on his views of Christianity. Apparently, he did not believe that the Indians stoning was reflective of the lessons he tried to teach them. 
there to deliver a message to George Croghan. The "Prince of Pennsylvania," George Croghan, who had an esteemed reputation among the Ohio Indians, saved Gist's life.

Gist soon left this hostile environment and continued westward to meet another Ohio Company employee, Barney Curran, and together they traveled to Muskingum, a Wyandot town that was equally divided in sympathies for the British and French. While Gist was at Muskingum, he met up with George Croghan and Andrew Montour. George Croghan was an esteemed "frontiersman" who was well liked by the Indians, and he was the most famous trader in Pennsylvania. Andrew Montour was of mixed French and Indian descent, his father was an Oneida and his mother was of Indian and French descent. Andrew (like his mother, Madam Montour) was a famous and sought after interpreter. Despite his French heritage, Montour worked mainly with the British. ${ }^{91}$ Gist told the two about of the Ohio Company and its plans for expansion into the region. Further east, there was intense rivalry between Pennsylvania and Virginia; but these tensions seemed to dissipate in the vast openness of the North American continent where British traders were far outnumbered. Christopher Gist, George Croghan and Andrew Montour collaborated on behalf of the British Crown during their brief spell together. ${ }^{92}$ This occurred when they engaged various Native American bands, mostly due to Montour's excellence as an interpreter. Gist noted that Croghan and Montour seemed pleased about the Ohio Company's plans, and both worked for the Company later. ${ }^{93}$ Croghan is another example of how the men in the Ohio Valley would cater to the British cause, tying their own fortunes to that of the British Empire.

\footnotetext{
${ }^{91}$ See Christopher Gist's Journals, 152-175, for more information on Madam and Andrew Montour.

${ }_{92}$ Christopher Gist's Journals, 55.

${ }^{93}$ Croghan, after a bad investment, lost his home in the borderlands and most of his money. Soon after this occurred he began to work for the Ohio Company, and was able to get a land grant for land adjacent to those claimed by the Ohio Company.
} 
Croghan owned a trading house at Muskingum, and he invited Gist to stay there with him. ${ }^{94}$ While Gist was present, several nearby British traders and Indians had been captured by French-allied Indians, and due to this emergency, Croghan held a conference with the British and Indians for the purpose of planning a rescue mission. During the proceedings, Gist announced that if the Indians would come to Logstown, and partner with the British, they would receive gifts from the Ohio Company. This conference, which was Gist's creation, would continue to grow until it was an inter-colonial event, attended by representatives from multiple colonies and numerous bands of Indians. ${ }^{95}$ The Indians at Muskingum agreed to attend. Gist's speech was followed by one from Montour, in which he advocated, "cleaning the French from the Channels of trade." ${ }^{.96}$ These talks apparently swayed the Indians, and Gist and Montour repeated their messages several times in the next few days, as they attempted to draw the Indians of the Ohio Valley away from the French. The Indians, who were against the French due to the recent kidnappings, received the messages delivered by Gist and Montour with pleasure.

After the council at Croghan's home at Muskingum, Gist, Croghan and Montour headed further west to Pickawillany, present day Piqua, Ohio. On the way there, they passed through several smaller Indian settlements that included bands of Delaware, Wyandot and Shawnee. At each of these encampments, Gist spread the word about the Council at Logstown and promised the Indians gifts if they came to meet with the Ohio Company. ${ }^{97}$

\footnotetext{
${ }^{94}$ Christopher Gist's Journals, 36.

${ }^{95}$ More information on the Conference at Logstown will be found later in the thesis.

${ }^{96}$ Christopher Gist's Journals, 37-41. The Twightwee's were a band of Miami Indians. This was a well-known Indian settlement at the time of Gist's explorations.

${ }^{97}$ Christopher Gist's Journals, 45.
} 
The group reached the Twightwee town of Pickawillamy on the 17 of February. ${ }^{98}$ Montour, who acted as the spokesmen for the group, gave a speech that stressed that the French needed to be excluded from trade in the Ohio region. He further advocated the benefits of engaging in trade with the British. For the next few days, many meetings and councils were held, in an attempt to gain the friendship of the Indians. Gist invited the Indians residing at Pickawillany to the conference at Logstown, and again promised them gifts if they would attend. On February 23 and 24, chaos broke out due to rumors of a French attack on the settlement. This was not the case, as only four French envoys came into the town with the purpose of swaying the Indians there to the French cause. ${ }^{99}$ The Twightwees sent the French away and reaffirmed friendship with the British. As a result of Gist's visit, the Indians of Pickawillany and the British were able to establish a stronger alliance. On Gist's last day at Pickawillany, March 1, the Twightwees agreed to attend the conference at Logstown. ${ }^{100}$

On March 2, Gist parted ways with his companions, Croghan and Montour, but they would be reunited again soon at the Logstown Conference. It should be noted that both would serve as Indian ambassadors or interpreters at this event. Because the pro-French Indians had threatened the travelers earlier, Gist did not take the known Indian path. Rather he stuck to the lower branch of the Miami River, where he was forced to create his own route home due to the hostile environment. Due to this detour, he unexpectedly came across a "beautiful" meadow, which he later recommended to the Ohio Company for their settlement and land grant. ${ }^{101}$ The Ohio Company, however, saw this land as too far away from other settlements. Officials rejected his advice and later sent him on a second exploration with orders to stay

\footnotetext{
${ }^{98}$ Christopher Gist's Journals, 36.

${ }^{99}$ Christopher Gist's Journals, 48-49.

${ }^{100}$ Christopher Gist's Journals, 50.

${ }^{101}$ Bailey, The Ohio Company, 96.
} 
closer to home. Gist continued west within fifteen miles of the Falls of the Ohio, but due to increased French and Indian activity and rumors of their aggressive intent, he began the return journey home.

During Gist's return to the east, he found more signs of pro-French Indian activity, this time much closer to home. His family (his wife as well as his adult children and their families) had fled their home "at the edge of empire" in the Yadkin River Valley to seek temporary shelter and protection in the eastern settlements of North Carolina. All of his family members were safe, and after a short visit with them, Gist continued to Williamsburg to deliver his report to the members of the Ohio Company. ${ }^{102}$ The Gist family, because of the Indian raids on settlements further south, did not return to the Yadkin River Valley but instead relocated to the western part of Pennsylvania.

The Ohio Company deemed the land Gist had recommended on the Miami River to be too far way and too difficult to protect. As a result, the Ohio Company continued to search for the perfect location for their settlement. Satisfied with the quality of Gist's first report, the members called on him again for their second scouting trip. With instructions similar to those of his first mission, Gist headed once again into the Ohio Country. He was to start in Oldtown, Cresap's home, and obtain from him as many Ohio Company horses as he deemed necessary. ${ }^{103}$ Gist's first instruction was to "look out \& observe the nearest \& most convenient Road you can find from the Company's Store at Will's Creek to a landing on the

${ }^{102}$ It is important to note that Thomas Lee and Lawrence Washington had both passed away by this point, and new leadership was formed. Many, such as Governor Dinwiddie, George Mercer and Thomas Cresap attempted to fill their shoes, but without the success of their predecessors. It is debatable if this was due to character flaws or if the window of time for success in such a venture had closed.

${ }^{103}$ Christopher Gist's Journals, 67. 
Mohanglyela."104 Company officials further instructed Gist to travel down the south side of the Ohio until he came to the Big Kanawha, then follow the river as far as necessary. He was to find good land and make extensive descriptions and measurements (using surveying methods) of the land and rivers. He was also to identify areas where the Ohio Company could possibly build trading and storehouses. ${ }^{105}$

As Gist looked for locations that would be suitable for storehouses and trading posts, he again encountered diverse bands of Indians. Gist was the first British contact that most of the tribes living in that area had ever made. Some were refugees or had relocated from lands further east and had seen and dealt with Anglo-Americans previously, but to most of the Indians, Gist and the Ohio Company were unknown entities. ${ }^{106}$ This excursion gave Gist the chance to observe the people of these unexplored regions and a chance to secure their friendship for the British Empire. Also, and probably of more interest to the Ohio Company and the Crown, was the claim that Gist's excursion gave them on the newly explored and surveyed lands.

Gist would not leave on this second expedition until early November of 1751. This time he took his adult son with him. They traveled westward, past present-day Confluence, Pennsylvania until Gist came to a piece of land, which he claimed and marked for his family to settle. This area became known as "Gist's Landing." On December 7, 1751, Gist encountered the well-known Delaware Indian, Nemacolin, and invited him to the "Treaty at

104 Christopher Gist's Journals, 67.

${ }^{105}$ Christopher Gist's Journals, 67.

106 The Ohio region was also a borderland between the Indians who had fled west due to European arrival earlier, and those Indians who had lived there for centuries. Refugees and native inhabitants formed conglomerate settlements of many types of Indians all throughout the Ohio River Valley. 
Logstown, [during] the full moon in May."107 On December 9 he reached the Monongahela. Gist spent a lot of time in this area, mapping, surveying and exploring the region. Although Gist does not explain why in his journals, it would make sense for him to limit his range because the Ohio Company did not want a settlement too far out of reach. Gist acquainted himself to Indians in the region (around Licking Creek), specifically one named

Oppaymolleah, who inquired about Gist's presence "so far in the woods."108 Gist explained that he was there to invite the Indians of the region to the Logstown Conference. It seems that Gist, in his explorations, used the conference as an excuse to be in lands that were not secured for the British Crown.

Toward the end of his journey, Gist found a few rocks with veins of yellow; he took a sample for the Ohio Company, and then chiseled:

\section{THE OHIO COMPANY}

FEBY 1751

\section{BY CHRISTOPHER GIST ${ }^{109}$}

Gist marked the land for the Ohio Company, similar to what Céleron and his party had done when they claimed the land with physical markings. Soon after he marked this land for Britain, Gist turned east, and took a different route home. Gist noted several possible routes in his journal for the Ohio Company, which Company traders later used for quicker access

${ }^{107}$ Christopher Gist's Journals, 68.

${ }^{108}$ Christopher Gist's Journals, 71-74.

${ }^{109}$ Gist used the new style of dating, but he carved this according to the old style of dating. The actual date was February 1752. 
into the Ohio. After Gist's return, he engaged in other work for the Ohio Company, and he was unable to give the members his journal until October of 1752.

After his jaunt as a diplomat, Gist was allowed little relief. Thomas Cresap and Gist undertook a huge project that would become one of the major accomplishments of the Ohio Company. They marked and surveyed the road from "Philadelphia to the western lands." Ohio Company minutes show that Gist was appointed to assist Cresap in April of 1752. What began as a footpath or an animal trace became a packhorse route for traders and an extremely rough wagon road that went from Wills Creek (near present day Cumberland, Maryland) to the Monongahela. The purpose of this road was to lead settlers into the Ohio River Valley, and to mark the quickest way west for the Ohio Company traders. These settlers and traders, enabled by Cresap and Gist's path to the Ohio Valley, became a major source of tension between the British and French that led to the Seven Years' War. The Ohio Indians, as well as the French, were unhappy with the influx of British settlers who encroached on lands each considered to be their own. The French subsequently took preliminary steps to further entrench themselves in the Ohio Region.

The process of this massive undertaking is well documented in the journals of Christopher Gist, ever since he had been appointed by Company officials to travel with Cresap. Cresap and Gist were to find and mark the road that the Ohio Company hoped to build. ${ }^{111}$ Thomas Cresap also chose his own companion, the Delaware Indian, Nemacolin. When Cresap asked for his assistance in building the road, Nemacolin agreed to help as long

\footnotetext{
${ }^{110}$ Bailey, The Ohio Company, 153.

${ }^{111}$ Bailey, The Ohio Company Papers, 53.
} 
as the trail would be named after him. ${ }^{112}$ Cresap quickly agreed to these terms; he had some knowledge of the land that lay ahead, certainly more than any other member of the Ohio Company, but Nemacolin had much more knowledge than either Cresap or Gist possessed and was to offer the best trail through the woods. ${ }^{113}$

If Cresap, Gist and Nemacolin had not built and marked Nemacolin's Trace, many Anglo-American settlers would not have migrated at that time into the Ohio Country. These settlers added stress to the already tense relationship between Briton and France.

Subsequently, this road through the Ohio Country wilderness became even more connected to the British imperial effort; Nemacolin's Trace is the road that Braddock traveled and improved upon at the onset of the Seven Years' War. ${ }^{114}$ If Braddock had not taken and expanded the Ohio Company's road, the history of the war would be very different. If Cresap, Gist and Nemacolin had not carried out the Ohio Company's preliminarily work, the British would have had a significantly more difficult job upon their arrival to America, and the disputed territory would have been much more inaccessible.

This passage west would spur even more international controversy beyond the Seven Years' War, since it influenced Pontiac's Rebellion and the Revolutionary War. Because Nemocolin's Trace was an easy route to free land, the British government could not stem the flow of its subjects into "Indian Territory." The British government found it impossible to stop their subjects from moving west, despite the Royal Proclamation of 1763, which forbid

\footnotetext{
112 Bailey, The Ohio Company Papers, 52.

${ }^{113}$ Cresap and Nemacolin had a well-documented friendship. Nemacolin once nursed Cresap's son Daniel back to health after a nearly fatal encounter with a bear at the site of what would become known as "Dan's Rock," which is today a Maryland State Park.

114 This path is the route that the present day National Road loosely follows, so the route that Cresap, Gist and Nemacolin chose ended up being important for the future. This would become the United States' first national project that was decreed necessary to allow economic development for the new nation.
} 
Anglo-American colonists from moving into the Ohio River Valley. Settlers traveled west on the road that had been marked by the employees of the Ohio Company, and expanded by Braddock's March; the settlers had a direct and tempting route to "free" land.

The conference that Gist had advertised all year took place at Logstown in the spring of 1753. This conference would mark a change in the relationship of the British and the Indians who lived in the Ohio Valley, but before the conference or its consequences can be examined, a brief explanation of the Ohio Indian situation and the Half- King Tanaghrisson is necessary. Understanding the political situation in the Ohio Valley is crucial to understanding the importance of each individual's actions and their contributions to the conference at Logstown.

Tanaghrission, the half-king, with whom the British were trying to negotiate, was already on rocky ground with his "constituents." His influence among the Ohio Indians was limited due the nature of his position as Half King. The Iroquois had appointed him to control the Delaware, Mingo and other Indians whom the Iroquois considered "conquered." The Iroquois saw the Delaware especially as their "little brothers". The Ohio Indians were unhappy with this arrangement, and continually looked for ways to break their strained and forced bond with the Iroquois Confederation. If Tanaghrisson made an unpopular decision, his position, as well as the position of the Iroquois Confederation would be seriously endangered.

Due to the fluid, impermanent nature of Indian politics, the power of most Indian leaders was never absolute. Indian leaders had to first gain and then constantly endeavor to maintain power. Individual status as a leader could be lost easily if the people did not agree with the headman's decisions. If the leader sold tribal lands, or engaged in risky and harmful 
warfare, he risked loosing the support of his people. The Logstown conference promised friendship, gifts and military alliances, but it also threatened settlement and land loss. The situation was tense and was further complicated by language barriers. The situation required skilled diplomacy by both parties.

The Indian political game was not the only one with intricacies. The Logstown Conference, demonstrates the tangle that was Virginia politics in the early 1750's. It was a private but government approved enterprise that spearheaded the expansion of the colony. Virginia set up a conference in order to confirm that a private enterprise would be able to attain its goals, and then used an employee of the company to invite the Indians to the conference. All of this is doubly confusing because Gist was there as an agent for the Ohio Company, although he was not a member, but Ohio Company members were there acting on the behalf of the Virginia council and not the Company. It should be remembered that this entire conference might have been one of Gist's flashes of brilliance, as he improvised to keep his scalp.

As time went on, the reason for the Logstown Conference evolved into a reaffirmation of the Treaty of Lancaster, which the Indians had repudiated, at least in the view of the Virginians. The Indians' view of the Lancaster agreement prohibited the Ohio Company from erecting any permanent settlements in the Ohio Country. Several initiatives were addressed by the Ohio Company, but the original reason the conference was called was to regain Indian friendship so they could erect a settlement. This proved difficult because the coureur de bois and the Pennsylvania traders had previously spread rumors about the Ohio Company's intentions. Neither the French nor the Pennsylvanians wanted to lose the Indian trade to their Virginian competitors. The Ohio Company intended to give gifts and reaffirm their right to 
construct a settlement in the Ohio Country, which they believed had been previously granted at the Treaty of Lancaster. Dinwiddie, who arrived from England during the winter planning of the conference, expounded upon these plans and made a rather extensive list of goals.

Dinwiddie greatly expanded the purpose of the conference and invited other colonial governors to partake in the treaty, although no others attended. ${ }^{115}$ George Croghan was "sent" as an unofficial delegate from Pennsylvania, and Andrew Montour attended as an interpreter. Pennsylvania Governor Hamilton requested that Montour stress to the Indians that the Pennsylvania government was in agreement with the Virginians. ${ }^{116}$

Due to the rumor mongering of the Pennsylvania traders, the conference did not start on its intended date of April 28, 1752 but rather on June 1, of that year. George Mercer was the new head of the Company since Thomas Lee and Lawrence Washington had both passed away. Mercer asked Gist to be the Ohio Company's agent at the conference. Paradoxically, the reason for this decision was that Gist had gained immense popularity among the Indians despite the failing reputation of the Ohio Company. ${ }^{117}$

The Logstown Conference demonstrates how the Ohio Company dominated colonial interaction with the Indians. It was at this conference that the Treaty of Lancaster was renewed and plans for the Ohio Company settlement revealed to the Indians for the first time. Virginia was willing to go to great lengths to get the land the Ohio Company wanted; proof of this was that they were willing to repurchase the land they believed they had already

\footnotetext{
${ }^{115}$ Governor Dinwiddie's aims outside their effects on the Ohio Company and its employees will not be thoroughly investigated in this paper, but additional information can be found in, Robert Dinwiddie: His Career in American Colonial Government and Westward Expansion by Louis Koontz.

${ }^{116}$ Bailey, The Ohio Company,

${ }^{117}$ According to all the sources perused in the writing of this paper, Gist was popular due to his friendly manner and fair trading practices.
} 
purchased at Lancaster. Also, the number of Ohio Company members and employees who were involved in either planning or participating in the Logstown Conference was overwhelming; this attendance alone shows the importance of the event. Gist and many other members of the Ohio Company were present. George Croghan and Andrew Montour, the interpreter for the conference, were both employees of the Ohio Company by this time as well. If the conference did not go the way the Company wanted, Gist's was to salvage the situation for the Ohio Company. He was instructed to purchase the land, for the Ohio Company, from the Indians around the forks of the Ohio, and please the Indians at almost any cost. There was even the possibility that Gist would act in an official capacity. The Virginia Council deemed that if one of the Virginia representatives was unable to attend the Conference, Gist was to act as an "imperial representative." This appointment demonstrates Gist's popularity with the Ohio Indians, the Ohio Company and the colonial Virginian government.

How exactly the Ohio Company obtained the results they did is still historically hazy, but it cannot be questioned that their agents knowledge of the Indian situation in the Ohio Country gave them an advantage. While they strengthened their relationships with all the Indians who attended, such as the Delaware, Shawnee, Wyandot, and Twightwee, they worked privately with the Seneca Half-King Tanaghrisson in order to achieve their goals. ${ }^{118}$ The deal that resulted in the Half-King allowing the Ohio Company to erect a fort and settlement was done by what Francis Jennings called "the boys in the backroom." 119

\footnotetext{
118 Tanaghrisson was the appointed "half-king" of the Iroquois Confederation over the Ohio Indians.

${ }^{119}$ Francis Jennings, Empire of Fortune, 43.
} 
In the general conference, the Ohio Company could not reach an agreement with the Indians that would allow the proposed and long awaited settlement in the Ohio River Valley. Thus, the empire builders had to resort to a more scheming method. A separate, private conference was set up between the Ohio Company and Virginia agents and the Iroquois Half King. Tanaghrisson. Tanaghrisson initially agreed that the Ohio Company could place a fort and trading post at the Three Rivers area (modern day Pittsburgh), because this would protect the Indians from the increasing hostile French threat and provide access to cheaper European goods. Tanaghrisson did not, however, agreed to allow a settlement there. After concessions (i.e. lots of "gifts") from the Ohio Company, the Half King agreed to a private meeting, where he finally agreed to allow the settlement. The only problem with this arrangement was that as a Half King, Tanaghrisson did not really have the political power to make any such agreement. Only the Iroquois Council at Onondaga could "sell" Iroquoian lands.

The Iroquois Council ignored the fact that Tanaghrisson had made an "illegal" land sale. In order to keep the delicate power balance in the Ohio Country tipped in their favor, it was necessary. The French were a threat to both the Iroquois and the other diverse bands living in the Ohio Valley. Tanaghrisson, as well as others on the Iroquois Council were aware that they needed allies such as the British. The promise of a British fort that offered protection was desirable. The Council and the Half King just had to accept that the settlement came with the British alliance.

This conference offers an example of Indian agency. Tanaghrisson was aware of the lead plates Céleron de Blainville had buried in the ground and claims to French power that accompanied them, and he understood the Anglo-American hunger for land. The Half King's power was already in jeopardy among the Indians he was supposed to be leading. Therefore, 
he could not afford to let control of the Ohio Country or the heaps of British goods slip through the fingers of the Iroquois Confederation. "Half kings" often maintained power through gift giving. Many of the gifts that Indian leaders used came from European traders. The cheaper these goods were the more political favor a leader could buy with his people. Because of all these issues, Tanaghrisson accepted the Ohio Company's gifts and then used them as patronage for the conquered bands of Ohio Indians. He was willing to do so because of the combined material and political value of the gifts. Accepting the gifts was a symbol of support from the Indians that would continue after the conference.

The agreement with Tanaghrisson was not the only repercussion of the Logstown Conference. The next day, the pro-British settlement at Pickawillany was destroyed by the French allied Ottawa, and soon after Marquis Duquesne moved to assert more French control in the Ohio, mainly through a plan to build forts. The French were unhappy with the British encroachment into the backcountry and were quick to ensure that they would not fall behind the British. The Indian agent for Pennsylvania, Richard Peters asserted that the Ohio Company had made a mistake, "the French have taken their Rise from the Imprudent and high Talk of the Virginians, as if they would immediately build Forts and settle the Ohio Lands. This they should have done and not talked on it so long beforehand, it has alarmed the French too soon." 120 The French heard the rustle of the Ohio Company in the borderland and were not slow to respond. The erection of French forts was a logical counter-move. The Ohio Company had already erected trading posts and warehouses and after the Logstown Conference, they had obtained the permission from at least one group of Indians to carry out their settlement plans. Subsequently, the French, who lacked sufficient numbers to settle the

${ }^{120}$ Jennings, Empire of Fortune, 18. 
Ohio, would use military forts and Indian allies to keep the British confined to the eastern seaboard. Of course, such a bold move also affected the Indians of the Ohio Region. Twightwee leaders wrote to Dinwiddie on June 21, 1752 and told him that the French and their Indian allies (the Ottawa) had attacked their camp at Pickawillany and brutally murdered their headman, who was called Old Briton, because they had sided with the British. ${ }^{121}$ Dinwiddie sent some aid, but evidently not enough, for soon after this, the group split into pro-French and pro-British camps. ${ }^{122}$ The powerhouses fighting for control of the Ohio Valley did resort to brutality to sway the inhabitants. This strategy worked, for about half of the Twightwees cut their ties with the British and took on the French as their allies and moved to Detroit, while the rest dissipated into the conglomerate Indian settlements that were already present in the Ohio River Valley. ${ }^{123}$ These changes negated the political influence of the Twightwee tribe in the disputed territory. This was a major change in the political landscape of the Ohio Region and one that did not favor the British. The Ohio Company and the British had lost what they considered to be one of their most important Indian allies in the Ohio region. ${ }^{124}$

${ }^{121}$ Pontiac, the future leader of Pontiac's Rebellion, was a member of the Ottawa group who raided the Twightwee town. This serves as a reminder to those who study borderland activity that just because those in Europe had decided that the war for the Ohio Country was over did not mean their Indian counterparts agreed. The Indian interest in the Ohio River Valley did not desist after the Treaty of Paris had been signed, and the Ohio region remained disputed even after the end of the Seven Years' War.

122 Dinwiddie blames himself for the split of the Twightwees in a letter to Thomas Cresap. Dinwiddie, Robert. Robert Dinwiddie Correspondence Illustrative of his Career in American Colonial Government and Westward Expansion. Ed. Louis Knott Koontz. Berkeley: University of California Press, 1951.

${ }^{123}$ Jennings, Empire of Fortune, 187.

${ }^{124}$ In Christopher Gist's journal, he notes that he believes that the Twightwees were the most influential group on the North American Continent. 
The French were now on the offensive, and they built forts to protect their claim over the Ohio River Valley. Soon after this development, Company investors, who knew that their profits would be lost if the French were to have their way in the disputed region, sent Cresap, Gist and their newest employee, William Trent, to build a fort for the Ohio Company at the Forks of the Ohio River, as stipulated by the Logstown agreement with the Half-King. ${ }^{125}$ It should be noted that it was the Ohio Company of Virginia, not the British government or the Virginia colony that erected a fort in the disputed territory; it was a commercial enterprise with imperial undertones.

The French continued to build their forts, which hastened military activity in the Ohio Region, and Dinwiddie, who saw his potential returns on Ohio Company stock plummeting, took action. He sent George Washington and Christopher Gist to Fort le Bouf (present-day Waterford Pennsylvania, along Lake Erie) to inform the French that they were considered trespassers. ${ }^{126}$ Gist was a great aid to George Washington on his first trip into the Ohio Valley, but it was not until they were on the way home that Washington would fully appreciate Gist's services. The pair ran into a band of "French Indians," one of whom fired at Washington at point blank range, but Gist knocked the gun from the Indian's hand and the bullet missed the intended target. ${ }^{127}$ The next day, the duo built a raft to ford the Allegany River and Washington was thrown from the raft; he was saved by Gist who fished the youth out of the water. Gist had saved George Washington's life twice, and guided him home safely. Washington returned to Williamsburg, and Gist remained at the Three Rivers Area to work on the Ohio Company fort (near present day Pittsburgh). Washington was promptly

\footnotetext{
${ }^{125}$ It was this Ohio Company fort that Braddock was sent to recover from the French when he reached America.

${ }^{126}$ Anderson, Crucible of War, 43.

${ }^{127}$ George Washington, The Journal of Major George Washington, 22.
} 
promoted by Dinwiddie and sent back to meet Gist in the Ohio Country. This time Washington and Gist were accompanied by troops from Virginia. While he was in the Ohio region, events transpired at Jumonville Glen that led to the hasty building of Fort Necessity. The skirmish that took place soon thereafter often marks the beginning of the Seven Years' War. Events after the Logstown Conference, such as Washington's excursion west to Fort LeBouf, are often the point where historians begin the story of the clash between the empires of Britain and France in America. This practice not only leaves out the important events that took place before 1753 , but it also leaves the common men who began the clash uninvestigated. Thus, the role of personal interest, ambition and commercial motivation are repeatedly underemphasized in the history of British Empire building in North America.

\section{Conclusion}

Although Christopher Gist dedicated most of his adult life to the cause of expanding the British Empire, his actions did not significantly benefit his financial situation in the long run. Although he acted as a guide and scout for Washington and General Braddock in the campaign into the Pennsylvania and Virginia backcountry, it was not a bullet that ended his life. He died of smallpox before the end of the Seven Years' War, though the exact date of his death is disputed (Gist had been on a diplomatic mission to the Catawba Indians in South Carolina), who had recently experienced a small outbreak of small pox. On the return trip

Gist too became ill). Despite the ambitious nature and various talents of Christopher Gist, he never regained his financial footing. This is partially because he had to continuously pay on his debt to the British Fur Company, and partially because he had to begin his settlement all 
over following the Indian attacks on "Gist's Plantation" in the early years of the Seven Years' War. Gist never received compensation from colony or Crown.

Thomas Cresap, on the other hard, survived the war. He later partook in the American Revolution, and afterwards, it is rumored, he temporarily returned to England for a national tour while in his eighties. Cresap returned to America with four of his late sister's daughters (Cresap's sister remained in England all her life). Cresap lived comfortably in his later years especially for "frontier" standards and he was able to engage and profit from land speculation and other "frontier" endeavors. Despite the fact that Cresap, like Gist, never received compensation for his wartime losses or the massive amounts of money he spent feeding the Indians, he was able to gain both wealth and status. ${ }^{128}$ Thomas Cresap continued to be a beacon along the route west. Oldtown, the place where both he and Gist had begun so many trips westward for the Ohio Company, continued to be a place of protection and respite for settlers and travelers.

Cresap and Gist's movements initiated repercussions that led to the outbreak to the Seven Years' War. These two men, who were road builders, trail blazers, and negotiators, had a profound effect on the commercial development of the American continent. The Ohio Company employees, attempting to add to their own fortunes along the way, forced the British to expand their empire. The tumultuous years that followed the Seven Years' War ensured that the Ohio Company members would never receive compensation for their imperial efforts. Although the remaining members struggled to keep the Ohio Company alive even after their country's independence had been achieved, it failed due to a variety of circumstances. It was hard to justify a land grant that was given by a country that no longer

\footnotetext{
${ }^{128}$ Although Cresap did at times receive compensation from the government, many times he did not and he paid out of pocket for the expense of feeding passing Indians.
} 
had any authority in its former colonies. The final nail in the coffin of the Ohio Company was Kentucky becoming a state in 1792, an event that ensured that the Ohio Company's dream of creating a settlement in the Ohio River Valley would never become a reality as their grant, like that of so many other pre-Revolutionary land speculation companies, was ignored by the newly independent United States government and the King of England.

The Ohio Valley was a tinderbox waiting for the first spark. Cresap and Gist acted as the flint and steel that caused the fragile strands of diplomacy to go up in smoke. Cresap and Gist, common men who lived and worked in or near the Ohio Country, were the ones who took action, in the name of the Ohio Company. Their actions had incredible repercussions on the borderland. These men worked to secure their own interests as well as those of the Ohio Company, which altered the course of the British Empire in North America. These two men, one who started his life as a debtor and ended up wealthy, and the other who started his life wealthy and ended as a debtor, were directly involved in the events that caused the Seven Years' War and the chaos that ensued in the Ohio Country. Thomas Cresap came up with the idea of the company, built its forts, blazed its roads, and engaged in trade and diplomacy with the Indians, including the powerful Iroquois Empire. Christopher Gist likewise erected forts, built roads, and engaged in Indian diplomacy; in addition, he acted as guide and scout for British colonial officials and engaged in two marathon excursions into foreign lands filled with unknown and mostly combative Indians. By protecting their own interests and those of the Ohio Company investors, Thomas Cresap and Christopher Gist helped extend the British Empire into the disputed Ohio Country. In the end, it was not the plans of London officials or the mutterings of Virginia elites that furthered the British cause in the Ohio River Valley and, indeed all of North American. It was those "on the ground" agents of empire that were 
common men who made an impact on the borderland. Common men, whose circumstances left them desperate and ambitious enough to claim the dangerous Ohio Valley, built the British Empire in the Ohio Valley. 
“And We do hereby strictly forbid, on Pain of our Displeasure, all our loving Subjects from making any Purchases or Settlements whatever, or taking Possession of any of the Lands above reserved without our especial leave and Licence for that Purpose first obtained. And We do further strictly enjoin and require all Persons whatever who have either wilfully or inadvertently seated themselves upon any Lands within the Countries above described. (sic) Or upon any other Lands which, not having been ceded to or purchased by Us, are still reserved to the said Indians as aforesaid, forthwith to remove themselves from such Settlements." 129

The Royal Proclamation, 1763

While 1776 will always be regarded as the year that changed the fate of America, 1763 should not be ignored. It was the Treaty of Paris of 1763 that officially ended conflict between the French and the British over the Ohio River Valley. The French Empire was officially erased off the map of North America, but the French people who lived in the Ohio Valley did not disappear. The terms of the treaty specified that Britain was required to take care of the French who remained in Canada and the Ohio Valley, and they had to allow those who practiced Catholicism to continue to worship as they pleased. To meet the terms of the Peace of Paris, British officials drew new lines on the North American map. In order to keep their new French constituents separate from their British colonists, and to respect the land claims of the Indians, the British government decided to forbid British settlement west of the

${ }^{129}$ The Proclamation of 1763. http://www.ushistory.org/declaration/related/proc63.htm 
Proclamation Line of 1763. The King and his Council were exercising more control in their American colonies than they ever had before.

The new excercising of authority of the British Empire in America ultimately caused its downfall. The Crown, seeking to reestablish control over its colonies in the difficult postwar period, exerted greater sovereign authority over its empire. The Proclamation Line, which was intended to limit conflict, actually may have increased it. The new proclamation cut off the Ohio Company of Virginia from its previously "granted" lands. Many individuals and groups had ventured into the west at the Crown's encouragement before the Seven Years' War, and after the Proclamation of 1763, they found that their settlements had been deemed illegal. The land that the Company members had been encouraged by London to settle, survey and fight for, was suddenly inaccessible. The Proclamation shocked the AngloAmerican colonists. The Ohio Country was suddenly a land they were unable to settle. Many colonists had fought in the Seven Years' War so that they could settle the Ohio Region. There were some members who believed that the Proclamation of 1763 was only temporary. George Washington, who had inherited interest in the Ohio Company from his late halfbrother, Lawrence, stated, "I can never look upon that Proclamation in any other light than as a temporary expedient to quiet the Minds of the Indians and must fall of course in a few years." 130 Unfortunately for the Ohio Company and its investors, this was not the case. The Company, confused by the Crown's sudden change in attitude, appealed repeatedly to the Board of Trade and to the King's Council to be allowed to take action on their land grant in the Ohio. George Mercer, the leader of the company at this time, wrote a petition in June 1765 pleading the Ohio Company's case, stating that he "most humbly Prays that your

${ }^{130}$ George Washington to William Crawford, September 21 1767, The George Washington Papers at the Library of Congress, 1741-1799. 
Majesty would... renew the said instructions to the Lieutt. Governor of Virginia;" in other words he hoped the King would allow the Ohio Company to resume planning for their settlement. ${ }^{131}$ He also asked if the Company could be reimbursed or given a land grant elsewhere in the "American Dominions." Mercer tried three more times, and once more after the American Revolution to contact the Council and the Board of Trade to revive the Ohio Company. Mercer's efforts were in vain, however, and seeing the turn of the tide, he did his best before his death to bring all the issues and business of the Ohio Company to a conclusion. He was almost successful in ending the unsuccessful Company's business, leaving only a few strands for his son to finish after his death.

In addition to their disgust with the British over their frontier policy, many colonists had other sources of anger. A great deal of the Anglo-Americans who had lived on the frontier suffered damages or losses either from the French, Indians or their own troops during the Seven Year's War. Some, like Cresap and Gist, tried to gain compensation for their losses but were turned away by the colonial governments of Maryland, Pennsylvania, Virginia and the British imperial government. These monetary losses only added to the growing dissatisfaction that the Anglo-American colonists felt towards their mother country. The British imposed blockade on the trans-Appalachian west, the uncompensated colonists, the taxes and regulations, and reestablished authority of the Crown over the colonies are among the reasons that those colonists, who only a few years before had been empire builders, became anti-colonial revolutionaries.

131 Memorial Of George Mercer on the Behalf of the Ohio Company, June 21 1765, Mulkearn, Lois, Ed, George Mercer Papers: Relating to the Ohio Company of Virginia. Pittsburgh; University of Pittsburgh Press, 1954. 
The self-interested actions of the Anglo-American colonists have been cited numerous times in the preceding pages. The individuals who toiled in the mountains found ways to work for the empire that benefitted British interests as well as their own. In following this line of reasoning then, it should come as no surprise that when those governing the British Empire went against the interests of the colonists who had built it, a clash would soon follow. Many members and employees of the Ohio Company were active in the American Revolution. Many of these men had spent most of their lives and much of their fortunes on expanding the empire into the Ohio Country. The Proclamation Line of 1763 negated the years these individuals had spent toiling to win the Ohio Country for the British Empire. The Proclamation Line slashed the egos and pocketbooks of those who had once been great empire builders, and the newly imposed taxes acted as salt in those open wounds. Thomas Cresap, George Washington, George Mercer and others who had built the British Empire in America turned their backs on London and fought for the colonies sovereignty. They revolted so that they -those who had opened the Ohio Valley to trade and settlement- could be the ones to determine the fate of the lands for which they fought.

Thomas Cresap, despite his aged years, was not content to sit back and hope that the Revolution would go in America's favor. By the time of the Revolution, Cresap was active in politics, representing the western section of Maryland in the Assembly, and he argued for resolutions in 1765 against the hated Stamp Act and protested against the "tyranny" of the Crown. It was also around this time that Cresap became active in the Sons of Liberty. Leaders in Frederick County, Cresap's county of residence, held a convention in 1773 to decide on the proper course of action. They decided to attend the Provincial Convention called by the colony of Maryland, and Cresap was elected as a delegate. At this convention, 
Cresap advocated that Maryland send delegates to the First Continental Congress. In 1775, Cresap was a member of Maryland's "Committee of Observation," where he was one of three people responsible for raising 1,330 lbs. for arms and ammunition from Frederick County. Cresap also influenced his family to participate as well. Cresap pledged a company of riflemen to the Second Continental Congress, and his son, Captain Michael Cresap, led the company north to Boston when George Washington made the call to arms. ${ }^{132}$ Cresap knew his days of earning money via British Empire building were over, and he saw his latest efforts being thwarted by that same empire. The British Empire would find its newest efforts to control the Ohio Valley thwarted by those who had attempted to established British control over the area only a few years prior.

The strife that began when the Ohio Company of Virginia struck out for the lands that lay beyond the summit of the Appalachian Mountains would find its conclusion at the end of the Revolution as the British were driven out of the thirteen colonies. However, this was not permanent and the struggle for dominance did not end at Yorktown. It continued throughout the first few decades of United States' history. As Fred Anderson writes in Crucible of War, "Perhaps we would be able to understand the founding of the United States differently... if we explained it not only in terms of political conflict... or the working out of Revolutionary ideals, but as a consequence of the forty year-long effort to subject the Ohio County, and with it the rest of the Trans-Appalachian west to imperial control." ${ }^{\text {"133 }}$ The imperialistic ambition to control the Ohio River Valley, along with the actions of self-interested individuals, dominates much of American history.

${ }^{132}$ Captain Michael Cresap was ill when he left Oldtown for Boston with his troops, and he was not able to make it past New York City, where he fell critically ill and died. He is buried beside Old Trinity Church in New York City.

${ }^{133}$ Fred Anderson, Crucible of War, $x x$. 


\section{Bibliography}

Secondary Sources

Adelmen, Jeremy and Aron, Stephen. "Borderlands and Borders: Empires, Nation-States, And the Peoples in Between in North American History" The American Historical Review, Vol. 104 No. 3 (June, 1999)

Allen, Irvin. Historic Oldtown, Maryland. Parsons West Virginia: McClain Printing Company, 2001.

Anderson, Fred. Crucible of War: The Seven Years' War and the Fate of Empire in British North America, 1754-1766. New York: Viking, 2005.

Anderson, Fred. The War that Made America. New York: Viking, 2005.

Aron, Stephen and Adelmen, Jeremy. "From Borders and Borderlands." American Historical Review (June, 1999): 814-841

Bailey, Kenneth compiled and edited, Ohio Company of Papers. Ann Arbor: Edwards Brothers, Inc., 1947

Bailey, Kenneth. Christopher Gist: Colonial Frontiersman, Explorer and Indian Agent. Hamden: Archon Books, 1976.

Bailey, Kenneth. Thomas Cresap, Maryland Frontiersman, Boston: Christopher Publishing House, 1944.

Bailey, Kenneth. The Ohio Company of Virginia and the Westward Movement 1784-1792. Lewisburg, Pennsylvania, 2000.

Bailyn, Bernard. The Peopling of British North America: An Introduction. Knopf, 1986.

Darlington, William ed. Christopher Gist's Journals; with Historical, Geographical and Ethnological Notes and Biographies of his Contemporaries. New York: Argonaut Press, 1966 .

Calloway, Colin, The Scratch of a Pen, 1763, and the Transformation of North America. Oxford: Oxford University Press, 2006.

Eckhart, Allan. The Frontiersmen. Boston: Little, Brown and Company, 1969.

Eckhart, Allan. The Wilderness Empire. Boston: Little, Brown and Company, 1967.

Furstenberg, François, "The Significance of the Trans-Appalachian Frontier in Atlantic History." The American Historical Review (June, 2008) 647-677 
Gregory Evans Dowd, A Spirited Resistance: The Struggle for North American Indian Unity, 1745-1815. Baltimore: The John Hopkins University Press, 1992.

Harrison, Fairfax, Virginia Land Grants: A Study of Conveyancing in Relation to Colonial Politics. Richmond 1925.

Hinderaker, Eric. Elusive Empires: Constructing Colonialism in the Ohio Valley, 1673-1800, New York: Cambridge University Press, 1997.

Jennings, Francis. The Ambiguous Iroquois Empire. New York, W.W. Norton and Company: 1984.

Jennings, Francis. Empire of Fortune. New York, W.W. Norton and Company: 1988.

Jennings, Francis. The Invasion of America, Indians, Colonialism, and the Cant of Conquest. New York: W.W. Norton and Company: 1990.

McConnell Michael. A Country Between: The Upper Ohio Valley and Its Peoples, 17241774, Lincoln: University of Nebraska Press, 1992.

Merritt, Jane. At The Crossroads: Indians and Empires on a Mid-Atlantic Frontier. Chapel Hill: University of North Carolina Press, 2003.

Morgan, Philip D. Strangers within the Realm: Cultural Margins of the First British Empire . Chapel Hill, North Carolina Press, 1991

Nobles, Gregory. "Breaking into the Backcountry" The William and Mary Quarterly, Third Series, Vol. 46, No. 4 (Oct., 1989) p. 643

Powell, Allan. Forgotten Heroes of the Maryland Frontier. Baltimore: Gateway Press, 2001.

Powell, Allan. Maryland and the French and Indian War. Baltimore: Gateway Press, 2001.

Proctor, James Alfred. The Ohio Company: Its Inner History. Pittsburgh: University of Pittsburgh Press, 1959.

Proctor, James Alfred. George Mercer of the Ohio Company: A Study in Frustration. Pittsburgh: University of Pittsburgh Press, 1963.

Turner, Frederick Jackson. The Frontier in American History. New York, Dover Publications Inc: 1996.

Ward, Matthew, Breaking the Backcountry: The Seven Years' War in Virginia and Pennsylvania, 1754-1765. Pittsburgh: University of Pittsburgh Press, 2003. 
White, Richard. The Middle Ground: Indians, Empires and Republics in the Great Lakes

Region, 1650-1815 (New York: Cambridge University Press, 1991

Wilson, Samuel. The Ohio Company of Virginia 1748-1798, Lexington: Kentucky Law Review, 1926.

Wroth, Lawrence. "The Story of Thomas Cresap; Maryland pioneer" Maryland Historical Magazine, Vol. IX March (1914).

\section{Primary Sources}

Abbot, W.W. et al., eds. The Papers of George Washington, Colonial Series, Vol. I. Charlottesville. VA. 1983.

Bailey, Kenneth ed., Ohio Company of Papers (The Suffering Trader Papers). Ann Arbor: Edwards Brothers, Inc., 1947.

Darlington, William, Ed. Christopher Gist's Journals with Historical, Geographical and Ethnological Notes and Biographies of his Contemporaries. Pittsburgh: J.R. Weldin \& Co., 1893.

Dinwiddie, Robert. The Official Records of Robert Dinwiddie, LieutenantGovernor of the Colony of Virginia, 1751-1758. In from the manuscript in The Collections of the Virginia Historical Society, ed. R.A. Brock. Richmond: The Society, 1883-84.

Dinwiddie, Robert. Robert Dinwiddie Correspondence Illustrative of his Career in American Colonial Government and Westward Expansion. Ed. Louis Knott Koontz. Berkeley: University of California Press, 1951.

Larrabee, Don ed., The Journals of George Washington and his Guide

Christopher Gist, on the historic mission to the French Forts in 1753. Williamsport: Unknown Publisher, 1950.

Mulkearn, Lois, Ed, George Mercer Papers: Relating to the Ohio Company of Virginia. Pittsburgh; University of Pittsburgh Press, 1954. 


\section{Appendix}

Appendix 1: Gist's Excursion 1750. 134

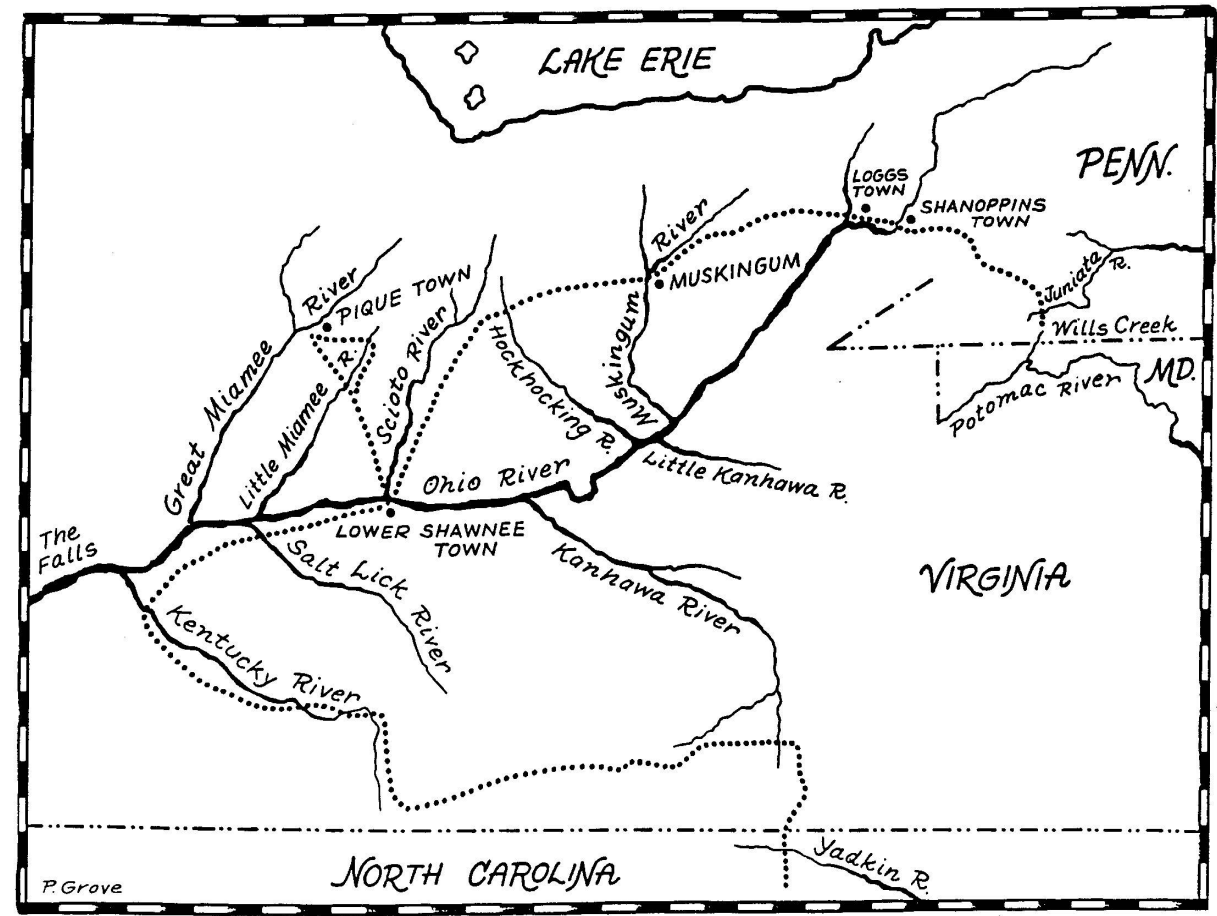

${ }^{134}$ Powell, Forgotten Heroes, 10. 
Appendix 2: Gist Excursion $1751^{135}$

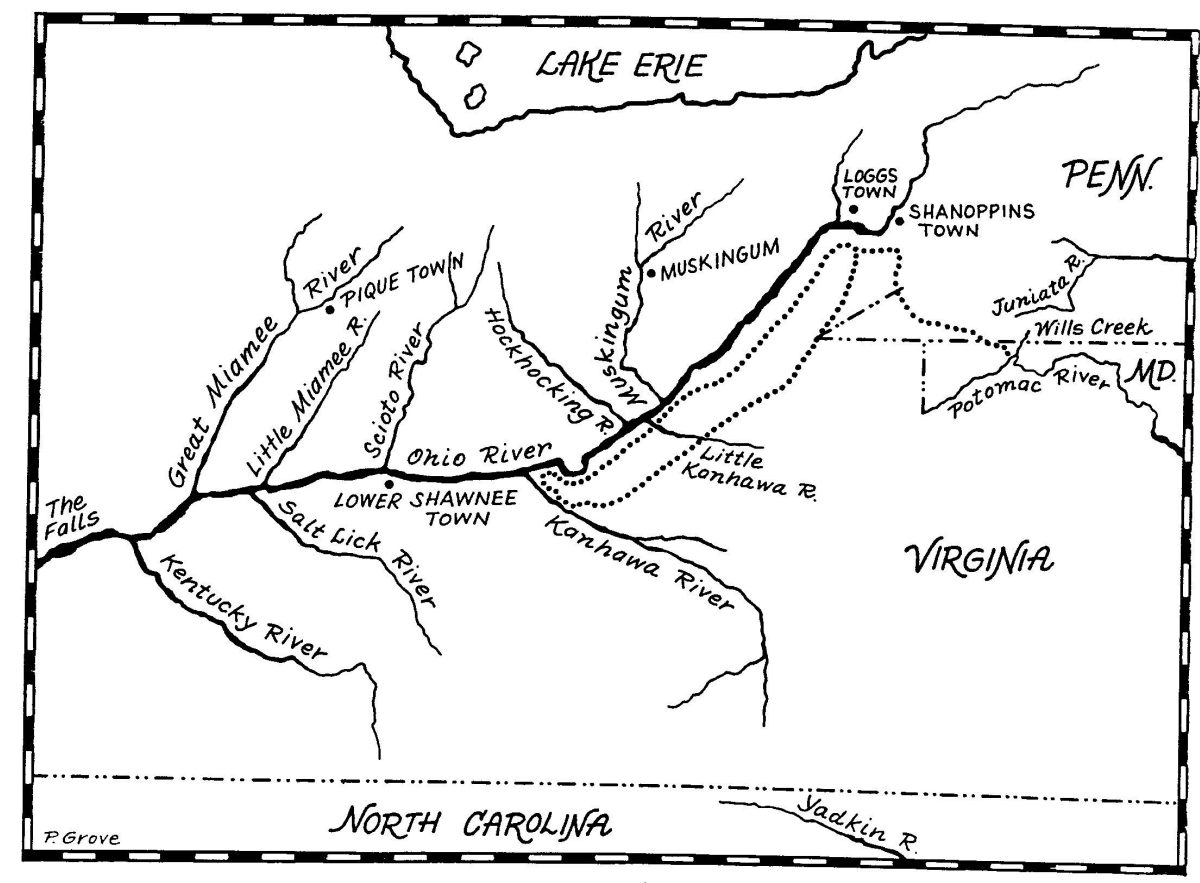

${ }^{135}$ Powell, Forgotten Heroes, 19. 
Appendix 3: Gist and Washington's Route to Fort Le Bouf 1753-1754. ${ }^{136}$

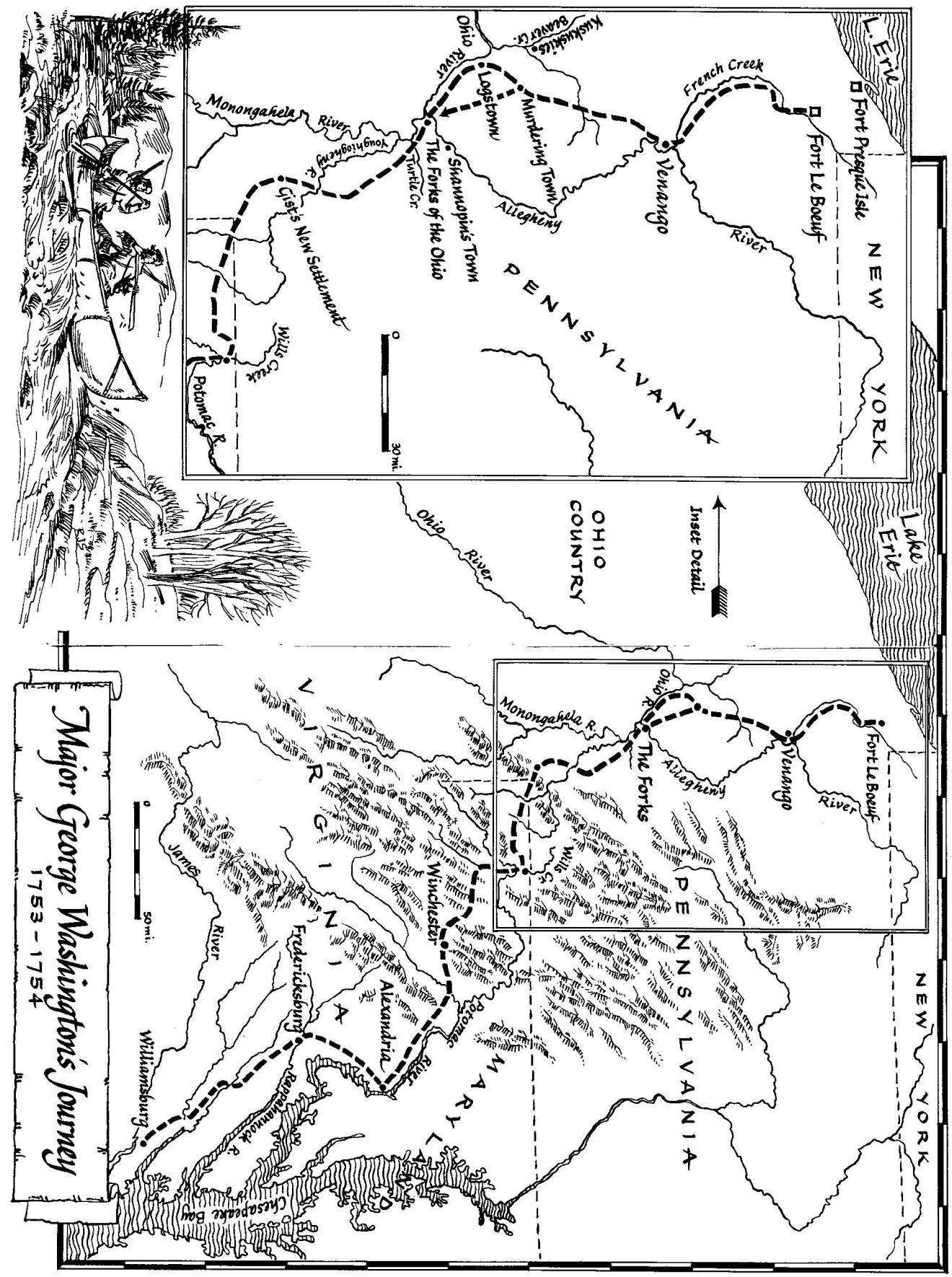

${ }^{136}$ George Washington, The Journal of Major George Washington, vii. 


\section{Curriculum Vitae}

Emily Hager

124 Pine Street

Frostburg, MD 21532

240-727-5314/ 301-689-5344

eshager0@gmail.com

Education:

Frostburg State University

2005-2009

BS in Political Science with concentrations in American Politics and in American Political Thought

BS in History with a concentration in American History

Graduate Summa Cum Laude (3.89)

Member of the Political Science, History and Freshmen Honors Societies Recipient of the Academic Excellence Scholarship

West Virginia University

2009-2011

MA in History (in progress) with concentrations in Colonial and Early American History

Recipient of the Ruth Regina Hale Scholarship

Thesis: Imperial Intentions and Independent Interests: The Ohio Company of Virginia and its Agents, Thomas Cresap and Christopher Gist, 1748-1752.

\section{Experience}

The Michael Cresap Museum- Maryland Historic Trust

Performed daily operations- including tours and interpretive programs

Directed the Cresap History Day Camp

\section{The Chesapeake and Ohio Canal National Historical Park} 2007-2011

Performed daily operations- managed the Visitor Center, Served as Point of Contact, gave and wrote interpretive park wide programs.

Recipient of the Star Award for two consecutive years

\footnotetext{
John H.

ou=Acquisitions Department

Hagen $\begin{array}{ll}\text { email=John.Hagen@mail.wvu.ed } \\ \text { u,c=Us } \\ \text { Date: } 2011.08 .01 \text { 09:35:51-04'00' }\end{array}$
} 